\title{
Organizational Form and the Economic Impact of Corporate New Product Strategies
}

\author{
Sheng-Syan Chen*
}

\begin{abstract}
This paper examines the role of organizational form in explaining the economic impact of corporate new product strategies. I find that the wealth effects associated with the announcements of new product introductions are more favorable for introducing firms with focused activities than for those with diversified activities. The results hold even after controlling for other factors suggested in the literature that could affect the value of new product introductions. The findings in this study suggest that the efficient investment hypothesis dominates the internal capital markets hypothesis in terms of the net economic impact of new product introductions on the introducing firms.
\end{abstract}

Keywords: focused firms, diversified firms, new product introductions, efficient investment hypothesis, internal capital markets hypothesis

\section{INTRODUCTION}

New product strategies are important corporate strategic investment decisions and are necessary to ensure the long-term vitality of a business firm. Previous studies have examined the economic impact of corporate new product introductions (e.g., see Chaney et al., 1991; Kelm et al., 1995; Chen and Ho, 1997; and Chen et al., 2002). They find that announcements of new product introductions are generally associated with a positive economic impact on shareholder value. New product introductions create opportunities for differentiation and competitive advantage, which can have a positive effect on the announcing firms' earnings and market values.

\footnotetext{
* The author is from the Department of Finance, College of Management, National Taiwan University, Taiwan. He wishes to thank Shao-Chi Chang, Dosoung Choi, Kim Wai Ho, Frank C. Jen, Cheng-few Lee, Andrew W. Stark (editor), and especially an anonymous referee, as well as seminar participants at the 2004 FMA Annual Meeting for helpful comments and suggestions. He would also like to thank Kim Wai Ho and Kueh Hwa Ik for providing some of the data used in this study. Hung-Sheng Chen, Chia Wei Huang and Wenchun Lin provided very capable research assistance. The author also gratefully acknowledges funding from the National Science Council of Taiwan (NSC93-2416-H002-055). (Paper received October 2005, revised version accepted May 2007. Online publication October 2007)
}

Address for correspondence: Sheng-Syan Chen, Department of Finance, College of Management, National Taiwan University, No. 85, Sec. 4, Roosevelt Rd., Taipei, Taiwan.

e-mail: fnschen@management.ntu.edu.tw 
Previous studies have also examined the source of the valuation effects of corporate new product strategies. Chaney et al. (1991) find that the value of a new product announcement is higher for firms in more technologically-based industries and for firms that make original- or multiple-product announcements, while it is lower for firms that make frequent product announcements. They also find that short-term interest rates have a negative impact on the value of new product introductions. Kelm et al. (1995) show that the wealth effects of new product announcements are negatively related to industry-wide $\mathrm{R} \& \mathrm{D}$ intensity and firm size and positively related to industry concentration and announcement frequency. Chen and Ho (1997) show that new product introductions by firms with good investment opportunities are generally regarded as worthwhile, and those by firms with poor investment opportunities are not. Lee et al. (2000) document that first-moving firms experience higher wealth gains than followers at the time of new product introductions. Chen et al. (2002) find that the market valuation of new product introductions is poorer for firms with higher free cash flow. Waarts and Wierenga (2000) and Chen et al. (2002) show that the nature of competitive interaction in an industry is important in assessing the effect of corporate product strategies on shareholder value.

Although the results of the above studies are insightful, they do not consider the role of organizational form in explaining the economic impact of corporate new product strategies. As documented by Lang and Stulz (1994), Servaes (1996), Chen (2006) and others, focused firms tend to have better investment opportunities than diversified firms. Since firms with better investment opportunities are more likely to invest in positive net present value (NPV) projects (Lang et al., 1991; Szewczyk et al., 1996; and others), focused firms are expected to make worthwhile investments. For focused firms, new product introductions are therefore expected to be positive NPV projects. Diversified firms, on the other hand, have poorer investment opportunities and tend to invest more in negative NPV projects (Stulz, 1990; Scharfstein, 1998; and Shin and Stulz, 1998), probably because of a cross-subsidization problem (Meyer et al., 1992; and Scharfstein and Stein, 2000), a relatively greater propensity to engage in 'empire building' (Jensen, 1986) or 'power grabbing' (Rajan et al., 2000), or weaker managerial incentives to maximize shareholder value (Denis et al., 1997; and Anderson et al., 2000). Hence, new product introductions by diversified firms are not likely to be positive NPV projects. These arguments suggest that corporate new product strategies are expected to be more worthwhile for introducing firms with focused activities than for those with diversified activities. I refer to the possibility that the market views new product introductions by focused firms as a relatively more likely signal of positive NPV projects as the efficient investment hypothesis.

Although the efficient investment hypothesis predicts a relatively unfavorable economic impact for diversified new product introducers, there is an alternative hypothesis predicting that corporate new product strategies create more value for diversified firms than for focused firms. A diversified firm's cash flows may provide a superior means of funding an internal capital market. Having an internal market to fund the firm's needs for capital offers several benefits to the firm (Martin and Sayrak, 2003; and Chen, 2006). First of all, internally-raised capital is less costly than funds raised in the external capital market. The firm avoids the transaction costs and the costs of overcoming information asymmetry problems when selling securities in the capital market. Furthermore, with an internal source of financing, the firm's managers can exercise superior decision control over project selection, rather than 
leaving the firm's investment decisions to the whims of less well-informed investors in the external capital market (Weston, 1970; and Williamson, 1986). When managers have superior information, they can do a better job of project selection and thus enhance firm value (Stein, 1997). In essence, a diversified firm can bypass the external capital market by shifting funds from operating divisions with poorer investment opportunities to operating divisions with better investment opportunities. Therefore, diversified firms allocate resources more efficiently, because they create a larger internal capital market. A version of this argument raised by Stulz (1990) and Fluck and Lynch (1999) is that diversified firms, by creating a larger internal capital market, reduce the underinvestment problem described by Myers (1977). These internal capital market arguments predict that diversified firms are more likely to make positive NPV investments than focused firms (Berger and Ofek, 1995). This suggests that corporate new product strategies are expected to be more worthwhile for introducing firms with diversified activities than for those with focused activities. I refer to the hypothesis that the market views new product introductions by diversified firms as a relatively more likely signal of positive NPV investments as the internal capital markets hypothesis.

This study aims to examine the role of organizational form in explaining the economic impact of corporate new product strategies through testing the efficient investment hypothesis versus the internal capital markets hypothesis. The economic impact is measured in terms of abnormal stock returns as well as the dollar changes in the market value of the announcing firms associated with the announcements of new product introductions (as in Chaney et al., 1991; and others). The abnormal stock returns and the dollar changes in the market value are the net effects on the wealth of stockholders of those firms that announce new product introductions. The efficient investment hypothesis predicts that the economic impact of such announcements is more favorable for new product introductions by focused firms than for those by diversified firms, because focused firms tend to have better investment opportunities and are more likely to make positive NPV investments. On the other hand, the internal capital markets hypothesis predicts that the economic impact associated with announcements of corporate new product strategies is more favorable for diversified firms, because with a larger internal capital market, diversified firms allocate resources more efficiently and are more likely to invest in profitable projects.

This paper examines a sample of firms that announced new product introductions during the period 1989-1999. I show that announcements of corporate new product introductions are, on average, associated with significantly positive valuation effects, which are consistent with previous evidence. I further divide the sample by firms with focused activities and those with diversified activities. It is shown that introducing firms with focused activities have significantly positive wealth effects associated with their announcements of new product introductions, whereas those with diversified activities have insignificant wealth effects associated with such announcements. In cross-sectional regression analyses of the economic impact, I document a significantly positive relation between the effect of new product announcements on shareholder value and the degree of corporate focus. The results hold even after controlling for other factors suggested in the literature that could affect the value of corporate new product introductions. My findings suggest that the efficient investment hypothesis dominates the internal capital markets hypothesis. Focused firms are more likely to make positive NPV investments and hence their new product investments are more worthwhile than those by diversified firms. 
The remainder of the paper is organized as follows. Section 2 describes the sample and reports summary statistics. Section 3 presents the event study results and Section 4 presents the cross-sectional regression results. The final section concludes.

\section{SAMPLE AND DESCRIPTIVE STATISTICS}

This section describes the sample design. It then shows how I measure the degree of corporate focus. The control variables and sample characteristics are also described in detail.

\section{(i) Sample Design}

An initial sample of announcements of new product introductions by firms listed on the New York Stock Exchange (NYSE) or the American Stock Exchange (AMEX) is collected from the Dow Jones News Retrieval Service (DJNRS) database and UMI's Wall Street Journal (WSJ) Ondisc database. ${ }^{1}$ Words and phrases and their synonyms commonly used to describe new product introductions are selected as keys for a database search routine. Examples are 'introduce,' 'new product,' 'unveil,' 'launch,' 'received approval,' 'to market,' 'test market,' 'begin selling,' along with other pertinent words and phrases. When a repeat announcement of a firm announcing a new product introduction is found in a different publication, the announcement that has the earliest date is chosen, because this is the earliest date when the information about the new product introduction is publicly available. The definition of announcement date is the date of the publication in which the company's initial announcement appears. The sample period is from January 1989 to December 1999.

I use the following sample selection criteria:

(1) The announcing firms must have daily stock price information available from the Center for Research in Securities Prices (CRSP) returns files.

(2) The announcing firms must have business-segment information available from the Compustat files.

(3) There are no other announcements five days before or five days after the initial announcement date in order to avoid any confounding events that could distort the measurement of the valuation effects on the announcing firms.

As industry differences are important in the decision of organizational form (Lang and Stulz, 1994; and Campa and Kedia, 2002), this study follows Hadlock et al. (2001) and Thomas (2002) by restricting the attention to new product introductions by singlesegment firms and multiple-segment firms that operate in similar industries. For each year, I identify all of the distinct industry segments (Compustat two-digit SIC codes) of the multiple-segment firms that introduce new products. I then identify all of the single-segment introducing firms in the sample that operate in one of these industries during the same introducing year. New product introductions by single-segment firms that are not in one of these industries are dropped from the sample. I also drop from the

1 As mentioned by Chaney et al. (1991), the sample from these data sources may not represent all new products. The sample here can be described as a sample of 'significant' new product announcements. 
Table 1

Sample Distribution by Calendar Year and Firm Type

\begin{tabular}{lccrc}
\hline Year & Single Segment & Multiple Segment & Total & Percent of Sample \\
\hline 1989 & 37 & 43 & 80 & 10.1 \\
1990 & 46 & 58 & 104 & 13.1 \\
1991 & 37 & 27 & 64 & 8.1 \\
1992 & 23 & 23 & 46 & 5.8 \\
1993 & 31 & 45 & 76 & 9.6 \\
1994 & 33 & 44 & 77 & 9.7 \\
1995 & 66 & 48 & 114 & 14.4 \\
1996 & 44 & 18 & 62 & 7.8 \\
1997 & 46 & 11 & 57 & 7.2 \\
1998 & 33 & 28 & 61 & 6.7 \\
1999 & 14 & 39 & 53 & 100.0 \\
Total & 410 & 384 & 794 & \\
\hline
\end{tabular}

Notes:

This table summarizes the distribution of 794 announcements of new product introductions by calendar year and firm type. The sample is collected from the Dow Jones News Retrieval Service (DJNRS) database and UMI's Wall Street Journal (WSJ) Ondisc database. The following sample selection criteria are used: (1) Initial announcement date needs to be clearly identifiable in DJNRS and WSJ; (2) Shares of the announcing firms are traded in either the NYSE or the AMEX; (3) The announcing firms must have daily stock price information available from the CRSP returns files; (4) The announcing firms must have business-segment information available from the Compustat files; and (5) There are no other announcements five days before or five days after the initial announcement date. All multiple-segment introducing firms have at least one segment with an industry (two-digit SIC code) counterpart among the single-segment introducing firms in the year of the new product introduction. Likewise, all single-segment introducing firms have an industry counterpart among the segments of the multiple-segment introducing firms in the year of the new product introduction.

sample those introductions by multiple-segment firms if the introducing firm does not have at least one segment in the same industry as a single-segment firm that introduces new products during the same year. Therefore, the final sample includes only new product introductions by multiple-segment firms that have at least one segment with an industry counterpart among the set of single-segment introducing firms during the same year, and only those introductions by single-segment firms that compose this set of counterparts.

The final sample comprises 794 announcements of new product introductions. Table 1 reports a distribution of the sample by calendar year and firm type. There is some clustering of announcements in the sample during 1989 through 1990 and during 1993 through 1995. On a daily basis, however, the announcements are noncontemporaneous. Of the 794 announcements in the sample, 410 are conducted by single-segment firms and 384 are conducted by multiple-segment firms.

\section{(ii) Measuring Corporate Focus}

Following Lang and Stulz (1994), Comment and Jarrell (1995), Denis et al. (1997) and others, I use Compustat business-segment data to calculate three different measures of corporate focus: (1) the number of segments; (2) a revenue-based Herfindahl index, calculated as the sum of the squares of each segment's revenue as a proportion of total revenue; and (3) an asset-based Herfindahl index, computed in the same way using 
the book value of identifiable assets of the segment. ${ }^{2}$ A revenue-based (an asset-based) Herfindahl index reflects the degree to which sales (assets) are concentrated in just a few of the firm's business segments. Therefore, the closer the revenue-based (assetbased) Herfindahl index is to one, the more the firm's sales (assets) are concentrated within a few of its segments.

Table 2 presents the summary statistics for the three measures of corporate focus grouped by whether the new product introducer has a single segment or multiple segments. The multiple-segment introducing firms in the sample have 4.122 business segments on average and 4 business segments at the median. The mean (median) revenue-based Herfindahl index is 0.447 (0.396) and the mean (median) asset-based Herfindahl index is 0.326 (0.307) for the multiple-segment introducing firms.

\section{(iii) Control Variables}

This study also controls for other potential variables suggested in the literature that could affect the economic impact of new product introductions (Chaney et al., 1991; Kelm et al., 1995; Chen and Ho, 1997; Lee et al., 2000; and Chen et al., 2002). The control variables are related to: (1) announcing firms' characteristics, which include investment opportunities, free cash flow, debt ratio, firm size, and $\mathrm{R} \& \mathrm{D}$ intensity; (2) industry characteristics, which include industry concentration, technological opportunities, and strategic interaction; and (3) product announcement characteristics, which include single- or multiple-product announcements, product newness, entry timing, and announcement frequency. Data on the firm and industry characteristics are obtained from the Compustat files and data on the product announcement characteristics are obtained from the DJNRS and WSJ articles. The summary statistics for these control variables, grouped by whether the new product introducer has a single segment or multiple segments, are also shown in Table 2. Differences in means and medians between the two groups are assessed using $t$-tests and Wilcoxon rank-sum tests, respectively.

I estimate investment opportunities by a simple measure of Tobin's $q(Q)$ : the ratio of the market value of the firm's assets to the book value of the firm's assets, where the market value of assets equals the market value of equity plus the liquidating value of preferred stock plus the book value of long-term debt minus the net working capital (as in Song and Walkling, 2000). ${ }^{3}$ This simple measure of $q$ for investment opportunities has been widely used in previous studies (Shin and Stulz, 1998; Chang and Chen, 2002; Hyland and Diltz, 2002; Thomas, 2002; Kim et al., 2005; and others). ${ }^{4}$ The

2 Specifically, the revenue-based or asset-based Herfindahl index, $H$, is measured as $H=\sum_{i=1}^{n}\left(S_{i} / \sum_{i=1}^{n} S_{i}\right)^{2}$, where $n$ is the number of segments and $S_{i}$ is the sales or assets attributable to segment $i$. I also use the following alternative measures of corporate focus: (1) the number of four-digit SIC codes assigned by Compustat (as in Comment and Jarrell, 1995); and (2) the entropy index (as in Palepu, 1985). The conclusions in this study remain unchanged.

3 Specifically, $q=(E+P+$ LTD - NWC $) /$ TA, where $E$ is the market value of equity, $P$ is the liquidating value of preferred stock, LTD is the book value of long-term debt, NWC is the net working capital, and TA is the book value of total assets. The conclusions in this study remain unchanged if the market value of the firm's assets is estimated as the book value of assets minus the book value of common equity plus the market value of common equity (as in Barclay and Smith, 1995a and 1995b; and others).

4 Chung and Pruitt (1994) show that at least $96.6 \%$ of the variability of Tobin's $q$ (based on Lindenberg and Ross, 1981) is explained by this simple measure of $q$. 
Table 2

Descriptive Characteristics by Firm Type

\begin{tabular}{|c|c|c|c|c|c|c|}
\hline \multirow[b]{2}{*}{ Variable } & \multicolumn{2}{|c|}{ Single Segment } & \multicolumn{2}{|c|}{ Multiple Segment } & \multicolumn{2}{|c|}{ Difference } \\
\hline & Mean & Median & Mean & Median & Mean & Median \\
\hline umber of segmen & 1.000 & 1.000 & 4.122 & 4.000 & -3.122 & -3.000 \\
\hline $\begin{array}{l}\text { Revenue-based Herfindahl } \\
\text { index }\end{array}$ & 1.000 & 1.000 & 0.447 & 0.396 & 0.553 & 0.604 \\
\hline Asset-based Herfindahl index & 1.000 & 1.000 & 0.326 & 0.307 & 0.674 & 0.693 \\
\hline$Q$ & 1.986 & 1.217 & 1.178 & 1.027 & $0.808^{* * *}$ & $0.190^{* * *}$ \\
\hline FCF & 0.132 & 0.143 & 0.143 & 0.148 & -0.011 & -0.005 \\
\hline DEBT & 0.177 & 0.176 & 0.264 & 0.264 & $-0.087^{* * *}$ & $-0.088^{* * *}$ \\
\hline SIZE & 19,955 & 4,429 & 32,389 & 16,649 & $-12,434^{* * *}$ & $-12,220^{* * *}$ \\
\hline FIRMRD & 1.487 & 1.113 & 1.417 & 1.023 & 0.070 & $0.090^{* * *}$ \\
\hline INDCON & 0.292 & 0.257 & 0.395 & 0.256 & -0.103 & 0.001 \\
\hline INDRD & 0.071 & 0.067 & 0.046 & 0.045 & $0.025^{* * *}$ & $0.022^{* * *}$ \\
\hline CSM & -0.002 & -0.004 & 0.059 & 0.057 & $-0.061^{* * *}$ & $-0.061^{* * *}$ \\
\hline MULTIPLE & 0.263 & 0.000 & 0.208 & 0.000 & $0.055^{*}$ & $0.000^{*}$ \\
\hline NEWNESS & 0.756 & 1.000 & 0.690 & 1.000 & $0.066^{* *}$ & $0.000^{* *}$ \\
\hline TIME & 0.580 & 1.000 & 0.565 & 1.000 & 0.015 & 0.000 \\
\hline FREQUENCY & 2.017 & 1.000 & 1.578 & 1.000 & $0.439^{* *}$ & $0.000^{*}$ \\
\hline
\end{tabular}

Notes:

This table presents summary characteristics by firm type. The revenue-based Herfindahl index is calculated as the sum of the squares of each segment's revenue as a proportion of total revenue, while the asset-based Herfindahl index is computed in the same way using the book value of identifiable assets of the segment. Tobin's $q(Q)$ is the average ratio of the market value of the firm's assets to the book value of the firm's assets for the three fiscal years before the announcement, where the market value of assets is estimated as the market value of equity plus the liquidating value of preferred stock plus the book value of long-term debt minus the net working capital. Free cash flow (FCF) is defined as operating income before depreciation minus interest expense, taxes, preferred dividends, and common dividends, all divided by the book value of total assets, for the fiscal year preceding the announcement. Debt ratio (DEBT) is the book value of total debt divided by the book value of total assets for the fiscal year prior to the announcement. Firm size (SIZE) is the book value of total assets for the fiscal year prior to the announcement (in \$ millions 1999). Relative firm R\&D intensity (FIRMRD) is defined as the intensity of the firm's R\&D effort (R\&D per dollar of net sales) divided by its industry's for the fiscal year prior to the announcement. Industry concentration (INDCON) is measured by the sum of the squared fraction of industry sales by all firms in the industry for the fiscal year prior to the announcement. Industry R\&D intensity (INDRD) is defined as R\&D expenditures by all firms in the industry divided by industry net sales. The competitive strategy measure (CSM) is defined as the coefficient of correlation between: (1) ratio of change in firm's quarterly net income to change in firm's quarterly net sales and (2) change in the rest-of-industry's quarterly net sales, over the period of 28 quarters prior to the announcement quarter. MULTIPLE equals one for multiple-product announcements, and zero for single-product announcements. NEWNESS equals one if the product is a high-newness product, and zero if it is an update. TIME equals one if the announcing firm is the first mover, and zero otherwise. Announcement frequency (FREQUENCY) is determined by the number of new product announcements made by an announcing firm within 12 months preceding the announcement date. Differences in means are assessed using a $t$-test and differences in medians are assessed using a Wilcoxon rank-sum test. Since the number of segments, the revenue-based Herfindahl index, and the asset-based Herfindahl index display no variation for the single segment firms, I do not report statistical differences between the two subsamples for these three variables. ${ }^{* * *},{ }^{* *}$ and ${ }^{*}$ represent $1 \%, 5 \%$ and $10 \%$ significance levels, respectively.

$q$ variable is the average $q$ for the three fiscal years prior to the announcement. ${ }^{5}$ High- $q$ firms are regarded as firms with good investment opportunities while low- $q$ firms are

5 This follows the approach used in Lang et al. (1991) and others. A three-year average gives a better estimate of a firm's true $q$ (Lang et al., 1989). The results are qualitatively similar if the $q$ variable over the last year prior to the announcement is used. 
regarded as firms with poor investment opportunities. Table 2 shows that single-segment introducing firms in the sample of new product introductions have a significantly higher $q$ than multiple-segment introducing firms. This result implies that focused firms tend to have higher growth options in their investment opportunity sets, consistent with the findings in Wernerfelt and Montgomery (1988), Lang and Stulz (1994), Berger and Ofek (1995), Servaes (1996), Hadlock et al. (2001), Hyland and Diltz (2002), Thomas (2002) and others. Since firms with better investment opportunities are more likely to invest in positive NPV projects (Lang et al., 1991; Szewczyk et al., 1996; Chen and Ho, 1997; and others), this suggests that new product investments made by focused firms will be more worthwhile than those made by diversified firms.

Following Lehn and Poulsen (1989), Lang et al. (1991), Lie (2000 and 2002), Gregory (2005) and others, I define the free cash flow ratio (FCF) as operating income before depreciation minus interest expense, taxes, preferred dividends, and common dividends for the fiscal year preceding the announcement, divided by the book value of total assets. ${ }^{6}$ Table 2 shows that there is no significant difference in free cash flow between single-segment and multiple-segment introducing firms in the sample.

The debt ratio (DEBT) is measured by the ratio of the book value of total debt to the book value of total assets for the fiscal year prior to the announcement (as in Chen and Ho, 1997; Chen et al., 2002; and others). Firm size (SIZE) is the logarithm of the announcing firm's book value of total assets for the fiscal year preceding the announcement (as in Chaney et al., 1991; Berger and Ofek, 1999; Thomas, 2002; and others).$^{7}$ For ease of comparison, the measure of firm size is converted to 1999 dollars using the Consumer Price Index. Relative firm R\&D intensity (FIRMRD) is defined as the intensity of a firm's R\&D effort (R\&D per dollar of net sales) divided by its industry's for the fiscal year prior to the announcement, where industry is defined by the four-digit primary SIC code in Compustat (as in Kelm et al., 1995; and Chen et al., 2002) . ${ }^{8}$ Table 2 shows that multiple-segment introducing firms utilize significantly more leverage and are significantly larger than single-segment introducing firms, consistent with the findings in Berger and Ofek (1995), Anderson et al. (2000), Hadlock et al. (2001), Lins and Servaes (2002) and Thomas (2002). Multiple-segment introducing firms also generally spend less on $\mathrm{R} \& \mathrm{D}$ than single-segment introducing firms, although only the median difference is statistically significant. This result is consistent with Anderson et al. (2000), Campa and Kedia (2002), Hyland and Diltz (2002) and Thomas (2002).

As for the industry characteristics, industry concentration (INDCON) is measured by the sum of the squared fraction of industry sales by all firms in the 4-digit primary SIC industry for the fiscal year prior to the announcement (as in Lang and Stulz, 1992; and Hendricks and Singhal, 1997). Technological opportunities at the industry level are measured by industry R\&D intensity (INDRD), where INDRD is defined as $\mathrm{R} \& \mathrm{D}$ expenditures by all firms in the 4-digit primary SIC industry divided by industry

6 Specifically, FCF $=($ EBIT + DEP - INT - TAX - DIV $) /$ TA, where EBIT is earnings before interest and tax, DEP is depreciation expense, INT is interest expense, TAX is tax paid, DIV is dividend paid on ordinary and preferred shares, and TA is the book value of total assets.

7 The results are qualitatively similar if firm size is measured by the firm's market value of total assets or sales for the year prior to the announcement.

8 As indicated by Guenther and Rosman (1994) and Kahle and Walkling (1996), the CRSP SIC codes are not very representative of the industries in which the firms actually operate, which can lead to imprecise inferences. Compustat SIC codes appear to be more reliable. 
net sales (as in Kelm et al., 1995).${ }^{9}$ I follow Sundaram et al. (1996) and Chen et al. (2002) to operationalize the nature of a firm's strategic interaction in an industry by constructing a competitive strategy measure (CSM). The CSM is defined as the coefficient of correlation between: (1) the ratio of change in a firm's quarterly net income to change in a firm's quarterly net sales and (2) the change in the rest-ofindustry's quarterly net sales, over the period of 28 quarters prior to the announcement quarter. ${ }^{10}$ The measure is negative when the competition is in strategic substitutes and positive when the competition is in strategic complements.

Table 2 shows that the degree of industry concentration is similar between singlesegment and multiple-segment introducing firms in the sample of new product introductions. Single-segment introducers, however, are in more R\&D-intensive industries than multiple-segment introducers, consistent with Campa and Kedia (2002). Singlesegment introducers also tend to compete on the basis of strategic substitutes while multiple-segment introducers tend to compete on the basis of strategic complements. Sundaram et al. (1995) show that the more R\&D intensive the firm is, the more it competes in strategic substitutes. Since single-segment introducing firms are more $\mathrm{R} \& \mathrm{D}$ intensive, they are more likely to compete on the basis of strategic substitutes than multiple-segment introducing firms.

Product announcement characteristics are identified using a structural content analysis on the news contents (as in Firth and Narayanan, 1996; and Lee et al., 2000). ${ }^{11}$ A pilot study is conducted to extract the relevant keywords for later characterization. Two rounds of content analysis are carried out to ensure the appropriateness of the classification. Three dummy variables are then created: MULTIPLE, NEWNESS, and TIME. MULTIPLE is equal to one for multiple-product announcements and zero for single-product announcements (as in Chaney et al., 1991; and Chen et al., 2002). NEWNESS is equal to one if the product is a high-newness product and zero if it is an update (as in Chaney et al., 1991). ${ }^{12}$ TIME equals one if the announcing firm is the first mover, and zero otherwise (as in Lee et al., 2000). ${ }^{13}$ I also determine the announcement frequency (FREQUENCY) by the number of new product announcements made by an announcing firm within twelve months preceding the announcement date (as in Chen et al., 2002). ${ }^{14}$

Table 2 shows that single-segment firms are more likely to introduce multiple products and high-newness products than multiple-segment firms, while there is no

9 Alternatively, I also use a dummy variable, which is equal to one if the announcing firm is in a hightechnology industry and zero otherwise, to proxy for technology opportunities at the industry level (as in Chan et al., 1990). The conclusions in this study remain unchanged.

10 Specifically, I use three elements to calculate the CSM: the announcing firm's net income, the announcing firm's net sales, and its rivals' net sales, where the net income is a proxy for profit and net sales a proxy for output. I define the set of rivals as all the firms with the same four-digit primary SIC code in Compustat except the announcing firm. I obtain seven years (i.e., 28 quarters) of data on quarterly net income and quarterly net sales, up to and including the quarter prior to the announcement quarter, from Compustat. I measure announcing firm's marginal profit by the ratio of change in its net income $\left(\Delta \pi^{A}\right)$ to change in its own net sales $\left(\Delta S^{A}\right)$. The CSM is the correlation coefficient between $\Delta \pi^{A} / \Delta S^{A}$ and the change in the rivals' net sales $\left(\Delta S^{R}\right)$ over the period of 28 quarters prior to the announcement quarter.

11 This approach is frequently used in the study of realized strategies and managerial cognitions.

12 For a product to be considered an update, the announcement has to explicitly specify that it is an update or an enhancement of an existing product.

13 The first firm to announce the introduction of a new product in the industry is considered the first-moving firm.

14 I also measure announcement frequency by the number of new product announcements over the 11-year sample period of the study (as in Chaney et al., 1991; and Kelm et al., 1995). The results are similar. 
significant difference in entry timing between the two groups. Single-segment firms also tend to be frequent product announcers. Cardinal and Opler (1995) show that the number of new product announcements is positively related to industry $R \& D$ intensity. Since single-segment introducing firms are in more R\&D-intensive industries, they are more likely to make frequent product announcements.

\section{EVENT STUDY RESULTS}

In this section, I first investigate the economic impact of new product introductions for the introducing firms as a whole. I then analyze subsamples stratified according to whether the introducing firm has a single segment or multiple segments.

\section{(i) Overall Sample}

I employ an event-study methodology to examine stock price responses to announcements of corporate new product introductions. Day 0 is defined as the initial announcement date. The abnormal return is calculated as the difference between the actual return and an expected return generated by the traditional one-factor market model. I use the value-weighted CRSP index as a proxy for market returns and estimate the parameters of the market model using data over the period from 200 to 60 days before the initial announcement date. ${ }^{15}$ Abnormal returns and cumulative abnormal returns are generated for each firm announcing a new product introduction over the period 30 days before to 30 days after the initial announcement date. Cumulative abnormal returns over the periods $(-30,-2),(-20,-2),(-10,-2),(-1,0),(1,10)$, $(1,20)$ and $(1,30)$ are separately calculated by summing up the daily abnormal returns over the respective periods. The two-day period $(-1,0)$ captures the price reaction to the new product announcement, while earlier periods capture the anticipation of the information, and later periods capture early revisions to the initial reaction of the new product introduction. I also compute the dollar changes in the market value of the announcing firms surrounding the announcements of new product introductions. Dollar changes in the market value of the firms during each respective period are computed by multiplying the cumulative abnormal returns over the period by the announcing firms' market of equity for the fiscal year preceding the announcement. For ease of comparison, the dollar changes in the market value are converted to 1999 dollars using the Consumer Price Index. Table 3 reports the results of the event study.

The average two-day $(-1,0)$ announcement-period abnormal return of the sample firms is $1.24 \%$, statistically significant at the $1 \%$ level. ${ }^{16}$ The median abnormal return is $0.35 \%$ (also significant at the $1 \%$ level) and $57.7 \%$ of the sample announcement effects are positive. At 1999 prices, the average and median two-day $(-1,0)$ dollar gains to the announcing firms are respectively $\$ 136.99$ million and $\$ 18.31$ million, both statistically significant at the $1 \%$ level. No significant abnormal returns and dollar changes in the

15 I also re-compute results using the CRSP equally-weighted index as a proxy for market returns and using alternative periods of data to estimate the parameters of the market model. Results are robust and available from the author upon request.

16 I also conduct significance tests in Table 3 using the Z-statistic, as described in Dodd and Warner (1983). Similar results are obtained. 
Table 3

Cumulative Abnormal Returns and Dollar Changes in the Market Value of the Announcing Firms for the Whole Sample: One-Factor Market Model

\begin{tabular}{lllll}
\hline $\begin{array}{l}\text { Period Relative to } \\
\text { the Announcement }\end{array} \quad$ Mean & t-statistic & Median & $\begin{array}{c}\text { p-value for the } \\
\text { Wilcoxon z-statistic }\end{array}$ & $\begin{array}{c}\text { Proportion Positive } \\
(\%)\end{array}$ \\
\hline
\end{tabular}

\begin{tabular}{lccrrr}
\hline Panel A: Cumulative & Abnormal Returns (in \%) & & & \\
{$[-30,-2]$} & 0.22 & 0.47 & 0.27 & 0.41 & 51.3 \\
{$[-20,-2]$} & 0.16 & 0.44 & 0.36 & 0.42 & 51.8 \\
{$[-10,-2]$} & -0.19 & -0.84 & -0.06 & 0.93 & 49.6 \\
{$[-1,0]$} & 1.24 & $8.21^{* * *}$ & 0.35 & $<0.01$ & 57.7 \\
{$[1,10]$} & -0.33 & -1.19 & -0.14 & 0.78 & 48.2 \\
{$[1,20]$} & -0.57 & -1.52 & 0.17 & 0.46 & 50.5 \\
{$[1,30]$} & -0.14 & -0.30 & 0.32 & 0.95 & 51.5
\end{tabular}

\begin{tabular}{lccccc}
\hline Panel B: Dollar Changes in the Market Value of & the Announcing Firms (in \$ Millions) \\
{$[-30,-2]$} & -51.27 & -0.40 & 8.16 & 0.80 & 51.3 \\
{$[-20,-2]$} & -72.35 & -0.71 & 6.12 & 0.67 & 51.8 \\
{$[-10,-2]$} & -80.07 & -1.14 & -0.41 & 0.51 & 49.6 \\
{$[-1,0]$} & 136.99 & $4.39^{* * *}$ & 18.31 & $<0.01$ & 57.7 \\
{$[1,10]$} & -10.73 & -0.14 & -4.27 & 0.92 & 48.2 \\
{$[1,20]$} & -68.81 & -0.59 & 4.35 & 0.85 & 50.5 \\
{$[1,30]$} & -54.56 & -0.44 & 10.28 & 0.35 & 51.5 \\
\hline
\end{tabular}

Notes:

This table presents the cumulative abnormal stock returns and dollar changes in the market value of the announcing firms surrounding the announcements of 794 new product introductions from 1989 to 1999. Cumulative abnormal returns are estimated using the standard one-factor market model procedure with parameters estimated for the period 200 days to 60 days before the announcement. Dollar changes in the market value of the firms are computed by multiplying the cumulative abnormal returns by the announcing firms' market value of equity for the fiscal year preceding the announcement. For ease of comparison, the dollar changes in the market value are converted to 1999 dollars using the Consumer Price Index. Day 0 in event time is the initial announcement date. ${ }^{* * *}$ represents a $1 \%$ significance level.

market value of the firms are observed preceding and following the announcement period. Therefore, announcements of corporate new product strategies are, on average, associated with significantly positive valuation effects, which are consistent with the findings in previous studies.

For robustness, I also employ three alternative models to obtain estimates of abnormal stock returns surrounding new product announcements: the Fama and French (1992 and 1993) three-factor model, the mean-adjusted returns model, and the market-adjusted returns model. ${ }^{17}$ Table 4 presents the two-day announcementperiod abnormal returns and dollar changes in the market value of the announcing firms from these three approaches. Results in Table 4 are consistent with those in Table 3 in that announcements of new product introductions are generally associated with a positive economic impact on shareholder value.

\section{(ii) Analysis of Subsamples}

Table 5 examines the importance of organizational form in explaining the announcement effect of corporate new product strategies. The sample firms are divided according

17 Fama and French develop a three-factor model in which excess returns are linearly related to market beta, size, and book-to-market risk factors. 
Table 4

Two-Day Announcement-Period Abnormal Returns and Dollar Changes in the Market Value of the Announcing Firms for the Whole Sample: Alternative Estimation Approaches

\begin{tabular}{|c|c|c|c|}
\hline & $\begin{array}{l}\text { Fama and French } \\
\text { Three-Factor Model }\end{array}$ & $\begin{array}{l}\text { Mean-Adjusted } \\
\text { Returns Model }\end{array}$ & $\begin{array}{l}\text { Market-Adjusted } \\
\text { Returns Model }\end{array}$ \\
\hline \multicolumn{4}{|c|}{ Panel A: Two-Day Announcement-Period Abnormal Returns (in \%) } \\
\hline Mean & 1.13 & 1.12 & 1.15 \\
\hline$t$-statistic & $7.39^{* * *}$ & $6.95^{* * *}$ & $7.47^{* * *}$ \\
\hline Median & 0.41 & 0.43 & 0.44 \\
\hline$p$-value for the Wilcoxon $z$-statistic & $<0.01$ & $<0.01$ & $<0.01$ \\
\hline Proportion positive $(\%)$ & 58.4 & 58.7 & 57.1 \\
\hline \multicolumn{4}{|c|}{$\begin{array}{l}\text { Panel B: Dollar Changes in the Market Value of the Announcing Firms Over the Two-Day } \\
\text { Announcement Period (in \$ Millions) }\end{array}$} \\
\hline Mean & 105.55 & 114.88 & 126.23 \\
\hline$t$-statistic & $3.45^{* * *}$ & $3.24^{* * *}$ & $4.05^{* * *}$ \\
\hline Median & 22.57 & 17.05 & 18.42 \\
\hline$p$-value for the Wilcoxon $z$-statistic & $<0.01$ & $<0.01$ & $<0.01$ \\
\hline Proportion positive (\%) & 58.4 & 58.7 & 57.1 \\
\hline
\end{tabular}

Notes:

This table presents the two-day $(-1,0)$ cumulative abnormal returns and dollar changes in the market value of the announcing firms around new product announcements using the Fama and French (1992 and 1993) three-factor model, the mean-adjusted returns model, and the market-adjusted returns model. Dollar changes in the market value of the firms over the two-day announcement period are computed by multiplying the two-day announcement-period abnormal returns by the announcing firms' market value of equity for the fiscal year preceding the announcement. The dollar changes in the market value are converted to 1999 dollars using the Consumer Price Index. T-tests and Wilcoxon signed rank tests are used to test the hypotheses that the means and medians are equal to zero, respectively. ${ }^{* * *}$ represents a $1 \%$ significance level.

to whether the announcing firms have a single segment or multiple segments. Panel A of Table 5, shows that single-segment introducing firms have a positive average twoday announcement-period abnormal return of $2.3 \%$, statistically significant at the $1 \%$ level. The median abnormal return for single-segment firms is $0.85 \%$, also statistically significant at the $1 \%$ level, and $63.4 \%$ of their sample announcement effects are positive. In contrast, the average and median two-day announcement-period abnormal returns for multiple-segment introducing firms are respectively $0.1 \%$ and $0.09 \%$, but they are not statistically significant. Only $51.6 \%$ of the sample announcement effects for multiple-segment introducing firms are positive. The mean difference between the announcement-period abnormal returns for single-segment and multiple-segment introducing firms is $2.2 \%$. A $t$ test shows that the mean difference is statistically significant at the $1 \%$ level. The equality of the median abnormal returns for the two groups can also be rejected at the $1 \%$ level, based on a Wilcoxon rank-sum Test.

Panel B of Table 5, shows that the average and median two-day announcementperiod dollar gains at 1999 prices to the single-segment introducing firms are respectively $\$ 243.3$ million and $\$ 22.58$ million, both statistically significant at the $1 \%$ level. In contrast, multiple-segment introducing firms experience respectively, only $\$ 23.47$ million and $\$ 5.44$ million of average and median dollar gains at 1999 prices over the two-day announcement period, both statistically insignificantly different from zero. The mean difference between the dollar gains for single-segment and 
Table 5

Two-Day Announcement-Period Abnormal Returns and Dollar Changes in the Market Value of the Announcing Firms for Subsamples Stratified According to Firm Type: One-Factor Market Model

\begin{tabular}{lccc}
\hline & Single Segment & Multiple Segment & Difference \\
\hline Panel A: Two-Day Announcement-Period Abnormal Returns (in \%) & & \\
Mean & 2.30 & 0.10 & 2.20 \\
$t$-statistic & $8.95^{* * *}$ & 0.81 & $7.72^{* * *}$ \\
Median & 0.85 & 0.09 & 0.76 \\
$p$-value for the Wilcoxon $z$-statistic & $<0.01$ & 0.43 & $<.01$ \\
Proportion positive (\%) & 63.4 & 51.6 & 11.8 \\
\hline Panel B: Dollar Changes in the Market Value of the Announcing Firms & & \\
Announcement Period (in \$ Millions) & & & \\
Mean & 243.30 & 23.47 & 219.83 \\
$t$-statistic & $5.80^{* * *}$ & 0.51 & $3.54^{* * *}$ \\
Median & 22.58 & 5.44 & 17.14 \\
$p$-value for the Wilcoxon $z$-statistic & $<0.01$ & 0.12 & $<0.01$ \\
Proportion positive (\%) & 63.4 & 51.6 & 11.8 \\
\hline
\end{tabular}

Notes:

This table presents abnormal returns and dollar changes in the market value of the announcing firms over the two-day $(-1,0)$ announcement period at the announcement of new product introductions for subsamples stratified according to firm type. Two-day announcement-period abnormal returns are estimated using the standard one-factor market model procedure with parameters estimated for the period 200 days to 60 days before the announcement. Dollar changes in the market value of the firms over the two-day announcement period are computed by multiplying the two-day announcement-period abnormal returns by the announcing firms' market value of equity for the fiscal year preceding the announcement. The dollar changes in the market value are converted to 1999 dollars using the Consumer Price Index. T-tests and Wilcoxon signed rank tests are used to test the hypotheses that the means and medians are equal to zero, respectively. Differences in means and medians are assessed using $t$-tests and Wilcoxon rank-sum tests, respectively. ${ }^{* * *}$ represents a $1 \%$ significance level.

multiple-segment introducing firms is \$219.83 million in 1999 dollars, statistically significant at the $1 \%$ level. The equality of the median dollar gains for the two groups can also be rejected at the $1 \%$ level.

The overall findings in Table 5 are consistent with the efficient investment hypothesis that corporate new product strategies are more worthwhile for introducing firms with focused activities than for those with diversified activities. Focused firms tend to have better investment opportunities and invest more in positive NPV projects. For these firms, new product introductions are more likely to be positive NPV projects. Therefore, the economic impact of new product announcements is more favorable for new product strategies by focused firms than for those by diversified firms. My findings appear to be inconsistent with the internal capital markets hypothesis. However, it should be noted that these two hypotheses are not mutually exclusive. A more cautious interpretation of the results is that the efficient investment hypothesis dominates the internal capital markets hypothesis in terms of the net effect on the new product introducing firms' abnormal returns and dollar gains.

To assess the robustness of the results, I also perform the analysis of subsamples using the Fama and French (1992 and 1993) three-factor model, the mean-adjusted returns model, and the market-adjusted returns model to estimate abnormal stock returns surrounding new product announcements. Table 6 presents the results from 
these three alternative approaches. Results in Table 6 are similar to those in Table 5: the wealth effects associated with the announcements of new product introductions are more favorable for introducing firms with focused activities than for those with diversified activities.

\section{CROSS-SECTIONAL REGRESSION RESULTS}

This section first reports the regression estimates of the wealth effects of new product announcements on organizational form. I then present the regression results controlling for other potential explanatory variables.

\section{(i) Regressions Without Controlling for Other Potentially Influential Factors}

Table 7 presents cross-sectional regression analyses of the economic impact of corporate new product strategies against organizational form. The $t$-values are computed with heteroskedasticity-consistent standard errors (White, 1980). Following Berger and Ofek (1995), Comment and Jarrell (1995), Denis et al. (1997), Campa and Kedia (2002) and Barnes and Hardie-Brown (2006), I use a dummy variable for corporate focus that is equal to one for focused firms (i.e. those with a single business segment) and zero for diversified firms (i.e. those with multiple business segments). To test the robustness of the results, I also replace the corporate focus dummy by the following three alternative measures of corporate focus: the number of business segments, the revenue-based Herfindahl index, and the asset-based Herfindahl index.

Panel A of Table 7, shows the results of the cross-sectional regression analyses of the announcement-period abnormal returns for the sample of new product introductions. I find that the coefficients for the focus dummy, the revenue-based Herfindahl index, and the asset-based Herfindahl index are all positive and statistically significant at the $1 \%$ level. The coefficient for the number of business segments is negative, also statistically significant at the $1 \%$ level. The results in Panel A, Table 7, suggest that the stock market responds more favorably to announcements of new product introductions by firms with focused activities. These findings again support that the efficient investment hypothesis dominates the internal capital markets hypothesis. Corporate new product strategies create more economic value for introducing firms with focused activities than for those with diversified activities since new product investments by focused firms are more likely to be positive NPV projects.

Panel B of Table 7, presents the results of the cross-sectional regression analyses of the dollar market value of the new product announcements. The results are similar to those in Panel A, Table 7. The coefficients for the focus dummy, the revenue-based Herfindahl index, and the asset-based Herfindahl index are all significantly positive, while the coefficient for the number of business segments is significantly negative. This evidence suggests that the dollar gains associated with new product introductions are more favorable for introducing firms with focused activities than for those with diversified activities. The overall results in Table 7 are consistent with those of Table 5 .

\section{(ii) Regressions Controlling for Other Potentially Influential Factors}

The analysis so far does not control for other potential determinants of the value of corporate new product strategies. The literature, however, suggests that several other 


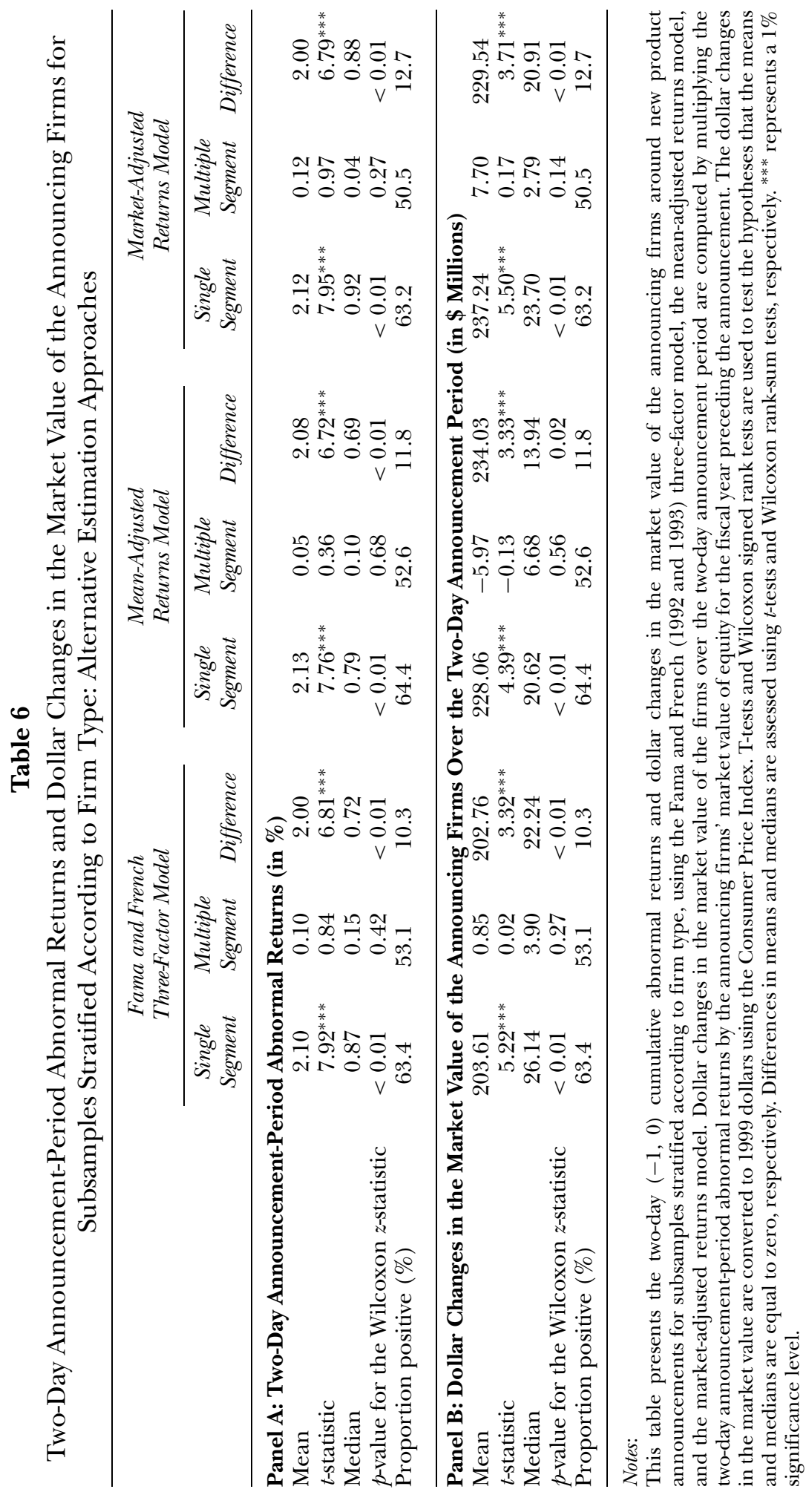


Table 7

Cross-Sectional Regression Analyses of Two-Day Announcement-Period Abnormal Returns and Dollar Changes in the Market Value of the Announcing Firms Against Organizational Form: One-Factor Market Model

\begin{tabular}{|c|c|c|c|c|}
\hline \multirow[b]{2}{*}{ Variable } & \multicolumn{4}{|c|}{ Model } \\
\hline & (1) & (2) & (3) & (4) \\
\hline \multicolumn{5}{|c|}{ Panel A: Dependent Variable $=$ Two-Day Announcement-Period Abnormal Returns } \\
\hline Intercept & $\begin{array}{l}0.0010 \\
(0.81)\end{array}$ & $\begin{array}{l}0.0231 \\
(8.54)^{* * *}\end{array}$ & $\begin{array}{l}-0.0110 \\
(-4.44)^{* * *}\end{array}$ & $\begin{array}{l}-0.0079 \\
(-3.97)^{* * *}\end{array}$ \\
\hline $\begin{array}{l}\text { Dummy equal to one for single- } \\
\text { segment firms (zero otherwise) }\end{array}$ & $\begin{array}{c}0.0220 \\
(7.73)^{* * *}\end{array}$ & & & \\
\hline Number of segments & & $\begin{array}{l}-0.0043 \\
(-6.82)^{* * *}\end{array}$ & & \\
\hline Revenue-based Herfindahl index & & & $\begin{array}{l}0.0319 \\
(7.42)^{* * *}\end{array}$ & \\
\hline Asset-based Herfindahl index & & & & $\begin{array}{c}0.0301 \\
(7.80)^{* * *}\end{array}$ \\
\hline$N$ & 794 & 794 & 794 & 794 \\
\hline Adjusted $R^{2}$ & 0.066 & 0.039 & 0.052 & 0.062 \\
\hline$F$-value & $57.07^{* * *}$ & $33.13^{* * *}$ & $44.43^{* * *}$ & $53.74^{* * *}$ \\
\hline \multicolumn{5}{|c|}{$\begin{array}{l}\text { Panel B: Dependent Variable = Dollar Changes in the Market Value of the Announcing Firms } \\
\text { Over the Two-Day Announcement Period }\end{array}$} \\
\hline Intercept & $\begin{array}{l}23.47 \\
(0.51)\end{array}$ & $\begin{array}{l}233.59 \\
(4.50)^{* * *}\end{array}$ & $\begin{array}{l}-60.74 \\
(-0.67)\end{array}$ & $\begin{array}{l}-28.54 \\
(-0.40)\end{array}$ \\
\hline $\begin{array}{l}\text { Dummy equal to one for single- } \\
\text { segment firms (zero otherwise) }\end{array}$ & $\begin{array}{l}219.83 \\
\quad(3.55)^{* * *}\end{array}$ & & & \\
\hline Number of segments & & $\begin{array}{l}-38.49 \\
(-1.97)^{* *}\end{array}$ & & \\
\hline Revenue-based Herfindahl index & & & $\begin{array}{l}269.98 \\
(2.42)^{* *}\end{array}$ & \\
\hline Asset-based Herfindahl index & & & & $\begin{array}{l}245.51 \\
\quad(2.73)^{* * *}\end{array}$ \\
\hline$N$ & 794 & 794 & 794 & 794 \\
\hline Adjusted $R^{2}$ & 0.014 & 0.006 & 0.008 & 0.009 \\
\hline$F$-value & $12.59^{* * *}$ & $6.06^{* *}$ & $7.10^{* * *}$ & $7.88^{* * *}$ \\
\hline
\end{tabular}

Notes:

This table presents cross-sectional regression analyses of abnormal returns and dollar changes in the market value of the announcing firms over the two-day $(-1,0)$ announcement period against organizational form for the sample of new product introductions. Two-day announcement-period abnormal returns are estimated using the standard one-factor market model procedure with parameters estimated for the period 200 days to 60 days before the announcement. Dollar changes in the market value of the firms over the two-day announcement period are computed by multiplying the two-day announcement-period abnormal returns by the announcing firms' market value of equity for the fiscal year preceding the announcement. The dollar changes in the market value are converted to 1999 dollars using the Consumer Price Index. The revenue-based Herfindahl index is calculated as the sum of the squares of each segment's revenue as a proportion of total revenue, while the asset-based Herfindahl index is computed in the same way using the book value of identifiable assets of the segment. The $t$-values in parentheses are computed with heteroskedasticity-consistent standard errors (White, 1980). ${ }^{* * *}$ and ${ }^{* *}$ represent $1 \%$ and $5 \%$ significance levels, respectively. 
factors could also influence the economic impact associated with the announcements of corporate new product strategies. I discuss these potentially important variables as follows.

Investment opportunities. Chen and Ho (1997) and Chen et al. (2002) find support for the investment opportunities hypothesis that new product strategies by firms with good investment opportunities are generally regarded as worthwhile, whereas those by firms with poor investment opportunities are not. Specifically, they find a significantly positive relation between a firm's Tobin's $q$ and its share-price response to a new product announcement.

Free cash flow. Jensen (1986) argues that managers endowed with free cash flow will invest in wasteful investments rather than pay it out to shareholders. New product investments may be one such use of this free cash flow (Chen and Ho, 1997). Therefore, the free cash flow theory predicts that the value of a new product announcement would be inversely related to the firm's level of free cash flow. Chen et al. (2002) report supporting evidence.

Debt ratio. Jensen (1986) suggests that firms with more free cash flow choose higher levels of debt in their capital structure as a credible pre-commitment to pay out the excess cash flow, hence lowering the expected costs of free cash flow. Jensen's theory implies a positive relation between the economic impact of new product introductions and the introducing firm's debt ratio. However, a firm's debt overhang could be large enough to prevent it from raising funds to finance positive NPV projects (Myers, 1977; Stulz, 1990; Phillips, 1995; Kovenock and Phillips, 1997; and Chen et al., 2005). Therefore, considering the two arguments together, the relation between the introducing firm's debt level and the economic impact of a new product introduction would be ambiguous. Chen and Ho (1997) and Chen et al. (2002) do not find a significant relation between abnormal return and debt ratio for their sample of new product strategies.

Firm size. New products should be more highly valued for small firms than for large firms, because small firms need product innovation to survive in the market while large firms introduce new products only to stay on top of the market (Chaney et al., 1991). In addition, large firms' new product introductions may have less unanticipated information than those of small firms as information production and dissemination is a positive function of firm size (Chaney et al., 1991; Kelm et al., 1995; and others). Therefore, firm size should be inversely related to the market valuation of new product introductions. Kelm et al. (1995) and Chen et al. (2002) document supporting evidence while Chaney et al. (1991) find mixed support.

REDD intensity. Kelm et al. (1995) argue that new product announcements by firms with high $\mathrm{R} \& \mathrm{D}$ intensity relative to their industry rivals carry less information for the stock market and hence create smaller wealth effects, since investors already expect these firms to make new product announcements. However, they find that the firm's R\&D intensity is not a significant factor in their sample of new product strategies. In contrast, Chen et al. (2002) argue that R\&D spending is an important source of intangible capital and product differentiation (Chauvin and Hirschey, 1993; and others). They find that the market values more highly those products that are announced by firms with high $\mathrm{R} \& \mathrm{D}$ intensity. 
Industry concentration. Industry concentration refers to the degree to which product markets are dominated by a small number of firms. Many economists have argued that the benefits of product innovation should be positively related to high market concentration as a firm with more monopoly power will make use of its dominant market position to reap a larger share of the profits in its product market. However, a greater industry concentration may also increase the risk of antitrust actions against the dominant firms (Bittlingmayer and Hazlett, 2000). ${ }^{18}$ While Kelm et al. (1995) document a positive relation between the market response to a new product introduction and the degree of industry concentration, empirical evidence from studies on the relation between the value of $\mathrm{R} \& \mathrm{D}$ spending and industry concentration produces mixed results. ${ }^{19}$ Kelm et al. (1995) argue that industry concentration is an important consideration during the commercialization stage when the market assesses the future cash flows from new products.

Technological opportunities. Chaney et al. (1991) argue that firms in more technologicallybased industries have greater technology opportunities and require new product innovations to stay alive. They also argue that the value of a new product innovation should be higher for firms in more technologically-based industries. They find some evidence supporting this hypothesis. In contrast, Kelm et al. (1995) argue that investors typically expect new product announcements by firms in more R\&D-intensive industries. ${ }^{20}$ Therefore, the intensity of the market reaction to new product announcements by these firms will be smaller. They show that investors respond positively to new product announcements by firms in less-technology-intensive industries.

Strategic interaction. Waarts and Wierenga (2000) and Chen et al. (2002) suggest that the impact of new product introductions on the introducing firms may depend on how their rival firms respond to the introductions. If the rivals accommodate the new product introducers by staying put, the expected impact on the introducers' profits and firm values will be positive and that on the rivals' will be negative. Bulow et al. (1985) describe this situation as competition in strategic substitutes. On the other hand, if the rivals respond to the introducers' product launches by adopting a matching strategy, the impact on the introducers' profits would be ambiguous. Although the product innovators can enjoy a temporary competitive advantage, they also incur costs in developing and introducing the new products that imitators do not bear (Mansfield et al., 1981). By imitating the innovators' actions, the rivals might reduce the competitive advantage enjoyed by the innovators and thus share in the profits (D'Aveni, 1994). Under this scenario, the introducers' wealth changes resulting from the new product announcements are ambiguous. Bulow et al. (1985) describe this situation as competition in strategic complements. Chen et al. (2002) document that new product introducers competing in strategic substitutes show a significantly positive announcing effect, whereas the valuation effect for those introducers competing in strategic complements is not significantly different from zero. Their evidence supports

18 Bittlingmayer and Hazlett (2000) find a negative impact of antitrust enforcement actions on Microsoft (as well as on a broad index of other computer stocks).

19 For example, Doukas and Switzer (1992) find a positive relation between the benefits of R\&D effort and high industry concentration, while Chan et al. (1990) show that industry concentration does not matter when R\&D intensity is controlled.

20 Industry R\&D intensity is often used as an indicator of the technological opportunity in an environment (Phillips, 1966; Comanor, 1967; Link and Long, 1981; Hambrick and MacMillan, 1985; and others). 
that the nature of competitive interaction in an industry is important in assessing the effect of corporate new product strategies on shareholder value.

Single- or multiple-product announcements. Firms introducing more products are likely to have more $\mathrm{R} \& \mathrm{D}$ expenditures, patented inventions, and skilled labor (Acs and Audretsch, 1988). They are also likely to be more competitive in the product market and seize more market share especially when the total market is growing very slowly (Hendricks and Singhal, 1997). This implies that multiple-product announcers may appropriate much of the benefits associated with the new products. Chaney et al. (1991) report that firms introducing multiple products experience more wealth gains than those announcing a single product.

Product newness. High-newness products are likely to be more successful and create better opportunities for product differentiation and competitive advantage (Kleinschmidt and Cooper, 1991). They are also expected to have a more positive impact on the new product introducing firms' cash flow (Chaney et al., 1991) and performance (Meyer and Roberts, 1986; and Firth and Narayanan, 1996). Therefore, high-newness products should receive a larger market value than updates of existing products. Chaney et al. (1991) find some evidence of more favorable market reactions to announcements of high-newness products.

Entry timing. The first to introduce a new product in the marketplace usually enjoys first-mover advantages. Lee et al. (2000) suggest that the first-mover advantages stem primarily from creation of entry barriers and switching costs, which serve to deter responses by rivals, and from high consumer recognition and preference to the first product. ${ }^{21}$ Lee et al. examine the impact of entry timing on the announcementperiod abnormal returns associated with new product introductions. They find that first-moving firms experience higher wealth gains than followers at the time of new product introductions. Jovanovic and MacDonald (1994) and Bernardo and Chowdhry (2002) also show that among the firms that expand, those that expand early have higher valuations.

Announcement frequency. Chaney et al. (1991) argue that factors expanding the information set available to investors about the product or firm should be negatively related to the size of the market impact seen at the time of product announcement. If a firm has a history of making frequent product announcements, the information value of a new product announcement is likely to be low. In contrast, Chen et al. (2002) argue that frequent product announcers are able to capitalize on follow-on investment projects and generate future investment opportunities. Therefore, new product announcements made by frequent announcers may elicit a more positive wealth effect. The empirical evidence is mixed. While Chaney et al. (1991) find that the frequency of new product announcements is negatively related to the announcementperiod return, Kelm et al. (1995) and Chen et al. (2002) document the opposite result.

In Table 8, I estimate the multivariate cross-sectional regressions of the economic impact of corporate new product strategies controlling for these factors. ${ }^{22}$ Due to

21 However, it is not always advantageous to move first. By moving first, the firm faces greater risk and market uncertainty, suffers pricing mistakes (Baldwin and Childs, 1969), and gives up some flexibility, which can be valuable (Trigeorgis, 1996; Saloner et al., 2001; and others).

22 The sample in Table 8 is smaller than that in Table 7, because of missing data on some of the control variables. 
Table 8

Cross-Sectional Regression Analyses of Two-Day Announcement-Period Abnormal

Returns and Dollar Changes in the Market Value of the Announcing Firms Against Organizational Form and Control Variables: One-Factor Market Model

\begin{tabular}{|c|c|c|c|}
\hline \multirow[b]{2}{*}{ Variable } & \multicolumn{3}{|c|}{ Model } \\
\hline & (1) & (2) & (3) \\
\hline \multicolumn{4}{|c|}{ Panel A: Dependent Variable = Two-Day Announcement-Period Abnormal Returns } \\
\hline Intercept & $\begin{array}{c}0.0625 \\
(2.75)^{* * *}\end{array}$ & $\begin{array}{c}0.0787 \\
(2.81)^{* * *}\end{array}$ & $\begin{array}{c}0.0789 \\
(2.74)^{* * *}\end{array}$ \\
\hline Revenue-based Herfindahl index & $\begin{array}{c}0.0109 \\
(2.91)^{* * *}\end{array}$ & $\begin{array}{c}0.0108 \\
(2.88)^{* * *}\end{array}$ & $\begin{array}{c}0.0110 \\
(2.91)^{* * *}\end{array}$ \\
\hline$Q$ & $\begin{array}{c}0.0033 \\
(2.16)^{* *}\end{array}$ & $\begin{array}{c}0.0031 \\
(2.05)^{* *}\end{array}$ & $\begin{array}{c}0.0030 \\
(2.01)^{* *}\end{array}$ \\
\hline FCF & $\begin{array}{c}-0.1145 \\
(-3.28)^{* * * *}\end{array}$ & $\begin{array}{c}-0.1136 \\
(-3.21)^{* * *}\end{array}$ & $\begin{array}{c}-0.1141 \\
(-3.26)^{* * *}\end{array}$ \\
\hline DEBT & $\begin{array}{l}-0.0147 \\
(-0.73)\end{array}$ & $\begin{array}{l}-0.0191 \\
(-0.87)\end{array}$ & $\begin{array}{l}-0.0194 \\
(-0.87)\end{array}$ \\
\hline SIZE & $\begin{array}{c}-0.0128 \\
(-3.34)^{* * *}\end{array}$ & $\begin{array}{c}-0.0128 \\
(-3.40)^{* * *}\end{array}$ & $\begin{array}{c}-0.0129 \\
(-3.42)^{* * *}\end{array}$ \\
\hline FIRMRD & $\begin{array}{l}0.0014 \\
(1.49)\end{array}$ & $\begin{array}{l}0.0013 \\
(1.38)\end{array}$ & $\begin{array}{l}0.0013 \\
(1.38)\end{array}$ \\
\hline INDCON & $\begin{array}{l}-0.0014 \\
(-0.22)\end{array}$ & $\begin{array}{l}-0.0011 \\
(-0.17)\end{array}$ & $\begin{array}{l}-0.0011 \\
(-0.18)\end{array}$ \\
\hline INDRD & $\begin{array}{l}-0.0099 \\
(-0.14)\end{array}$ & $\begin{array}{l}-0.0091 \\
(-0.13)\end{array}$ & $\begin{array}{l}-0.0071 \\
(-0.10)\end{array}$ \\
\hline CSM & $\begin{array}{l}-0.0042 \\
(-0.48)\end{array}$ & $\begin{array}{l}-0.0056 \\
(-0.65)\end{array}$ & $\begin{array}{l}-0.0051 \\
(-0.58)\end{array}$ \\
\hline MULTIPLE & $\begin{array}{l}0.0029 \\
(0.97)\end{array}$ & $\begin{array}{l}0.0033 \\
(1.13)\end{array}$ & $\begin{array}{l}0.0038 \\
(0.69)\end{array}$ \\
\hline NEWNESS & $\begin{array}{l}0.0039 \\
(1.08)\end{array}$ & $\begin{array}{l}0.0039 \\
(1.04)\end{array}$ & $\begin{array}{l}0.0073 \\
(1.26)\end{array}$ \\
\hline TIME & $\begin{array}{l}0.0007 \\
(0.20)\end{array}$ & $\begin{array}{l}0.0002 \\
(0.06)\end{array}$ & $\begin{array}{l}0.0025 \\
(0.40)\end{array}$ \\
\hline FREQUENCY & $\begin{array}{l}0.0008 \\
(1.57)\end{array}$ & $\begin{array}{c}0.0010 \\
(1.77)^{*}\end{array}$ & $\begin{array}{c}0.0010 \\
(1.80)^{*}\end{array}$ \\
\hline INTEREST & & $\begin{array}{c}-0.0020 \\
(-2.02)^{* *}\end{array}$ & $\begin{array}{c}-0.0020 \\
(-1.96)^{* *}\end{array}$ \\
\hline BETA & & $\begin{array}{l}-0.0039 \\
(-0.93)\end{array}$ & $\begin{array}{l}-0.0039 \\
(-0.94)\end{array}$ \\
\hline MULTIPLE $\times$ NEWNESS & & & $\begin{array}{l}-0.0093 \\
(-1.01)\end{array}$ \\
\hline MULTIPLE $\times$ TIME & & & $\begin{array}{l}0.0006 \\
(0.06)\end{array}$ \\
\hline NEWNESS $\times$ TIME & & & $\begin{array}{l}-0.0062 \\
(-0.84)\end{array}$ \\
\hline MULTIPLE $\times$ NEWNESS $\times$ TIME & & & $\begin{array}{l}0.0111 \\
(0.83)\end{array}$ \\
\hline$N$ & 646 & 646 & 646 \\
\hline Adjusted $R^{2}$ & 0.298 & 0.301 & 0.299 \\
\hline$F$-value & $22.06^{* * *}$ & $19.55^{* * *}$ & $15.49^{* * *}$ \\
\hline
\end{tabular}


Table 8 (Continued)

\begin{tabular}{|c|c|c|c|}
\hline \multirow[b]{2}{*}{ Variable } & \multicolumn{3}{|c|}{ Model } \\
\hline & (1) & (2) & (3) \\
\hline \multicolumn{4}{|c|}{$\begin{array}{l}\text { Panel B: Dependent Variable = Dollar Changes in the Market Value of the Announcing Firms Over the Two-Day } \\
\text { Announcement Period }\end{array}$} \\
\hline Intercept & $\begin{array}{r}-1379.0097 \\
(-3.70)^{* * *}\end{array}$ & $\begin{array}{r}-1162.9681 \\
(-3.24)^{* * *}\end{array}$ & $\begin{array}{r}-1180.9644 \\
(-3.24)^{* * *}\end{array}$ \\
\hline Revenue-based Herfindahl index & $\begin{array}{l}377.6344 \\
(2.60)^{* * *}\end{array}$ & $\begin{array}{r}372.5869 \\
(2.56)^{* *}\end{array}$ & $\begin{array}{r}368.6839 \\
(2.50)^{* *}\end{array}$ \\
\hline$Q$ & $\begin{array}{l}61.3110 \\
(1.81)^{*}\end{array}$ & $\begin{array}{l}58.6484 \\
(1.75)^{*}\end{array}$ & $\begin{array}{l}58.2781 \\
(1.72)^{*}\end{array}$ \\
\hline FCF & $\begin{array}{c}544.7927 \\
(1.45)\end{array}$ & $\begin{array}{c}527.1838 \\
(1.34)\end{array}$ & $\begin{array}{c}522.7552 \\
(1.32)\end{array}$ \\
\hline DEBT & $\begin{array}{c}-353.8811 \\
(-1.64)\end{array}$ & $\begin{array}{c}-371.2908 \\
(-1.55)\end{array}$ & $\begin{array}{c}-370.9694 \\
(-1.54)\end{array}$ \\
\hline SIZE & $\begin{array}{l}279.6854 \\
(3.67)^{* * *}\end{array}$ & $\begin{array}{l}279.1968 \\
(3.62)^{* * *}\end{array}$ & $\begin{array}{l}274.5159 \\
\quad(3.52)^{* * *}\end{array}$ \\
\hline FIRMRD & $\begin{array}{c}9.6868 \\
(1.95)^{*}\end{array}$ & $\begin{array}{c}9.4799 \\
(1.97)^{* *}\end{array}$ & $\begin{array}{c}9.2499 \\
(1.91)^{*}\end{array}$ \\
\hline INDCON & $\begin{array}{l}-68.3790 \\
(-0.37)\end{array}$ & $\begin{array}{l}-60.9601 \\
(-0.33)\end{array}$ & $\begin{array}{l}-61.4596 \\
(-0.33)\end{array}$ \\
\hline INDRD & $\begin{array}{c}1230.0460 \\
(1.58)\end{array}$ & $\begin{array}{c}1232.7409 \\
(1.58)\end{array}$ & $\begin{array}{c}1239.7821 \\
(1.61)\end{array}$ \\
\hline CSM & $\begin{array}{l}-40.2633 \\
(-0.18)\end{array}$ & $\begin{array}{l}-67.3295 \\
(-0.31)\end{array}$ & $\begin{array}{l}-68.3243 \\
(-0.32)\end{array}$ \\
\hline MULTIPLE & $\begin{array}{l}21.7658 \\
(0.33)\end{array}$ & $\begin{array}{l}28.4624 \\
(0.43)\end{array}$ & $\begin{array}{c}110.1089 \\
(0.88)\end{array}$ \\
\hline NEWNESS & $\begin{array}{l}-76.1756 \\
(-0.92)\end{array}$ & $\begin{array}{l}-84.1792 \\
(-1.00)\end{array}$ & $\begin{array}{l}-22.9365 \\
(-0.20)\end{array}$ \\
\hline TIME & $\begin{array}{l}91.1651 \\
(1.23)\end{array}$ & $\begin{array}{l}85.5191 \\
(1.16)\end{array}$ & $\begin{array}{c}115.9535 \\
(0.90)\end{array}$ \\
\hline FREQUENCY & $\begin{array}{l}-2.5666 \\
(-0.11)\end{array}$ & $\begin{array}{l}-0.6524 \\
(-0.03)\end{array}$ & $\begin{array}{l}-0.0794 \\
(-0.00)\end{array}$ \\
\hline INTEREST & & $\begin{array}{l}-33.0231 \\
(-2.07)^{* *}\end{array}$ & $\begin{array}{l}-30.9530 \\
(-1.89)^{*}\end{array}$ \\
\hline BETA & & $\begin{array}{l}-15.7254 \\
(-0.24)\end{array}$ & $\begin{array}{l}-13.6207 \\
(-0.21)\end{array}$ \\
\hline MULTIPLE $\times$ NEWNESS & & & $\begin{array}{c}-166.9544 \\
(-0.92)\end{array}$ \\
\hline MULTIPLE $\times$ TIME & & & $\begin{array}{c}115.9080 \\
(0.22)\end{array}$ \\
\hline NEWNESS $\times$ TIME & & & $\begin{array}{l}-66.5977 \\
(-0.39)\end{array}$ \\
\hline MULTIPLE $\times$ NEWNESS $\times$ TIME & & & $\begin{array}{l}-42.9963 \\
(-0.08)\end{array}$ \\
\hline$N$ & 646 & 646 & 646 \\
\hline Adjusted $R^{2}$ & 0.050 & 0.050 & 0.045 \\
\hline$F$-value & $3.60^{* * *}$ & $3.26^{* * *}$ & $2.60^{* * *}$ \\
\hline
\end{tabular}


Table 8 (Continued)

Notes:

This table presents cross-sectional regression analyses of abnormal returns and dollar changes in the market value of the announcing firms over the two-day $(-1,0)$ announcement period against organizational form and control variables for the sample of new product introductions. Two-day announcement-period abnormal returns are estimated using the standard one-factor market model procedure with parameters estimated for the period 200 days to 60 days before the announcement. Dollar changes in the market value of the firms over the two-day announcement period are computed by multiplying the two-day announcement-period abnormal returns by the announcing firms' market value of equity for the fiscal year preceding the announcement. The dollar changes in the market value are converted to 1999 dollars using the Consumer Price Index. The revenue-based Herfindahl index is calculated as the sum of the squares of each segment's revenue as a proportion of total revenue. Tobin's $q(Q)$ is the average ratio of the market value of the firm's assets to the book value of the firm's assets for the three fiscal years before the announcement, where the market value of assets is estimated as the market value of equity plus the liquidating value of preferred stock plus the book value of long-term debt minus the net working capital. Free cash flow (FCF) is defined as operating income before depreciation minus interest expense, taxes, preferred dividends, and common dividends, all divided by the book value of total assets, for the fiscal year preceding the announcement. Debt ratio (DEBT) is the book value of total debt divided by the book value of total assets for the fiscal year prior to the announcement. Firm size (SIZE) is the logarithm of book value of total assets for the fiscal year prior to the announcement (in 1999 dollars). Relative firm $\mathrm{R} \& \mathrm{D}$ intensity (FIRMRD) is defined as the intensity of the firm's R\&D effort (R\&D per dollar of net sales) divided by its industry's for the fiscal year prior to the announcement. Industry concentration (INDCON) is measured by the sum of the squared fraction of industry sales by all firms in the industry for the fiscal year prior to the announcement. Industry R\&D intensity (INDRD) is defined as R\&D expenditures by all firms in the industry divided by industry net sales. The competitive strategy measure (CSM) is defined as the coefficient of correlation between: (1) ratio of change in firm's quarterly net income to change in firm's quarterly net sales and (2) change in the rest-of-industry's quarterly net sales, over the period of 28 quarters prior to the announcement quarter. MULTIPLE equals one for multiple-product announcements, and zero for single-product announcements. NEWNESS equals one if the product is a high-newness product, and zero if it is an update. TIME equals one if the announcing firm is the first mover, and zero otherwise. Announcement frequency (FREQUENCY) is determined by the number of new product announcements made by an announcing firm within 12 months preceding the announcement date. Interest rate (INTEREST) is measured by the average of 90-day Treasury bill rates for the announcement year. Systematic risk (BETA) is estimated using daily stock returns and the CRSP value-weighted market returns for days -200 to -60 . The $t$-values in parentheses are computed with heteroskedasticity-consistent standard errors (White, 1980). The sample in Table 8 is smaller than that in Table 7 , because of missing data on some of the control variables. ${ }^{* * *},{ }^{* *}$ and ${ }^{*}$ represent $1 \%, 5 \%$ and $10 \%$ significance levels, respectively.

space considerations, I only present the results where the degree of corporate focus is measured by the revenue-based Herfinhahl index. Although not reported, the results are similar if the other three measures of corporate focus are used.

Panel A of Table 8, presents the results of the cross-sectional regression analyses of the announcement-period abnormal returns against organizational form and control variables for the sample of new product introductions. Model 1 shows that the revenuebased Herfinhahl index is still significantly positively related to the announcing firm's announcement-period abnormal returns when other potentially influential factors are controlled for. This indicates that corporate new product strategies are more worthwhile for introducing firms with focused activities than for those with diversified activities. The results again offer support that the efficient investment hypothesis dominates the internal capital markets hypothesis.

Model 1 also shows that several control variables are significant in explaining the announcement-period abnormal returns associated with new product introductions. The coefficient on $Q$ is positive and statistically significant. Therefore, it appears that firms with better investment opportunities experience more positive abnormal returns 
when they announce a new product investment. This result supports the notion that new product introductions by firms with good investment opportunities are generally regarded as more worthwhile than those by firms with poor investment opportunities (Chen and Ho, 1997; and Chen et al., 2002). Note that the coefficient on the revenuebased Herfindahl index in Model 1 is smaller than that in Model 3, Panel A, Table 7, though it remains positive and significant at the $1 \%$ level. This change is exactly what would be expected if focused firms have better investment opportunities and $Q$ partially proxies for the level of investment opportunities. The estimates in Model 1 are consistent with the hypothesis that $Q$ and the revenue-based Herfindahl index are both noisy measures of investment opportunities. Since focused firms tend to have higher levels of both the revenue-based Herfindahl index and $Q$, I interpret the estimates on these coefficients in Model 1 as adding further support for the efficient investment hypothesis.

I also find in Model 1 that the free cash flow variable (FCF) has a significantly negative impact on the announcing firm's share price response, as in Chen et al. (2002). This result is consistent with what would be expected under Jensen's (1986) free cash flow hypothesis. Model 1 further shows that the stock market's response to a new product announcement is significantly negatively related to the announcing firm's size (SIZE), consistent with the findings in Chaney et al. (1991), Kelm et al. (1995), and Chen et al. (2002).

To check the robustness of the results, I consider specifications where I add control variables to the basic regression in Model 1. In Model 2, I add two variables: interest rates (INTEREST) and the announcing firm's systematic risk (BETA). INTEREST is measured by the average of the 90-day Treasury bill rates for the announcement year and BETA is estimated using daily stock returns and the CRSP value-weighted market returns for days -200 to -60 (as in Chaney et al., 1991). ${ }^{23}$ Since the cost of capital depends on the level of interest rates, firms are expected to reduce their level of investment as expected interest rates rise. Furthermore, rising interest rates can imply a decline in product demand, thereby leading to a reduced cash stream of earnings from the product innovation. Therefore, a higher risk-free rate of interest is expected to have a negative impact on the market reaction to new product introductions (Chaney et al., 1991; and Chen et al., 2002). I also include the systematic risk of the announcing firm in the model, because Chaney et al. (1991) document that it has a significantly negative impact on the new product introducing firm's share price response.

Model 2 shows that after also controlling for INTEREST and BETA, the valuation effect of corporate new product strategies is still more favorable for introducing firms with focused activities than for those with diversified activities. The results for the control variables are similar to those in Model 1 except for the following. The coefficient of FREQUENCY becomes significantly positive in Model 2. This result, which is similar to the findings in Kelm et al. (1995) and Chen et al. (2002), is consistent with the notion that frequent announcers are able to capitalize on follow-on investment projects and generate future investment opportunities. Therefore, announcements by frequent announcers are associated with higher abnormal returns than those of less frequent announcers. Model 2 also shows that INTEREST has a significantly negative impact

23 Data on interest rates are obtained from the US Department of Commerce. The results are similar if the CRSP equally-weighted index is used as a proxy for market returns. 
on the market reaction to new product introductions, consistent with the findings in Chaney et al. (1991) and Chen et al. (2002), while BETA has no significant explanatory power.

In Model 3, I further control for four interaction terms, MULTIPLE $\times$ NEWNESS, MULTIPLE $\times$ TIME, NEWNESS $\times$ TIME, and MULTIPLE $\times$ NEWNESS $\times$ TIME, in addition to the variables in Model 2. Chaney et al. (1991) find that firms that introduce multiple original products experience the largest wealth impact, and those that introduce single-product updates show the smallest impact. Thus, the results in Chaney et al. (1991) suggest that the product announcer's share price response might be influenced by the interaction effect among MULTIPLE, NEWNESS, and TIME. However, Model 3 shows that these interaction terms do not appear important in explaining the announcing firm's share price response. The results for the other variables in the regression model remain essentially unchanged.

Panel B of Table 8, presents the results of the cross-sectional regression analyses of the dollar market value of the new product announcements against organizational form and control variables. It is shown that the dollar gains associated with new product introductions are more favorable for introducing firms with focused activities than for those with diversified activities even after other potentially influential factors are controlled for. This again supports that the efficient investment hypothesis dominates the internal capital markets hypothesis.

The results for the control variables in Panel B of Table 8, are similar to those in Panel A of Table 8, except for the following. FCF and FREQUENCY are no longer statistically significant at the conventional levels, suggesting that they are relatively unimportant in explaining the dollar gains associated with corporate new product strategies. The coefficient of FIRMRD becomes significantly positive once the economic impact is measured in terms of the dollar changes in the market value of the announcing firms associated with the announcements of new product introductions. This result, consistent with Chen et al. (2002), supports the view that R\&D spending is an important source of intangible capital and product differentiation and hence the market values more highly those products that are announced by firms with high R\&D intensity. Finally, the sign of SIZE is reversed and becomes significantly positive. This is similar to Chaney et al. (1991) who find mixed support for the role of firm size in explaining the economic impact of corporate new product strategies. ${ }^{24}$

To check the robustness of the results, I also perform the cross-sectional regression analyses using the Fama and French (1992 and 1993) three-factor model, the meanadjusted returns model, and the market-adjusted returns model to estimate abnormal stock returns surrounding new product announcements. Table 9 presents the results from these three approaches, where the explanatory variables include the revenuebased Herfinhahl index and all of the control variables used in this study. ${ }^{25}$ The findings in this study are robust to the alternative estimation techniques. The revenuebased Herfinhahl index is still significantly positively related to the announcing firm's announcement-period abnormal returns. The results for the control variables in the regression models are in general unaffected.

24 I have also included in the regression analyses year dummies and industry dummies (as in Chaney et al., 1991). The conclusions in this study remain unchanged.

25 The results are similar if the other three measures of corporate focus are used. 
Table 9

Cross-Sectional Regression Analyses of Two-Day Announcement-Period Abnormal Returns and Dollar Changes in the Market Value of the Announcing Firms Against Organizational Form and Control Variables: Alternative Estimation Approaches

\begin{tabular}{|c|c|c|c|}
\hline Variable & $\begin{array}{l}\text { Fama and French } \\
\text { Three-Factor Model }\end{array}$ & $\begin{array}{l}\text { Mean-Adjusted } \\
\text { Returns Model }\end{array}$ & $\begin{array}{c}\text { Market-Adjusted } \\
\text { Returns Model }\end{array}$ \\
\hline \multicolumn{4}{|c|}{ Panel A: Dependent Variable = Two-Day Announcement-Period Abnormal Returns } \\
\hline Intercept & $\begin{array}{c}0.0804 \\
(2.79)^{* * *}\end{array}$ & $\begin{array}{c}0.0825 \\
(2.78)^{* * *}\end{array}$ & $\begin{array}{c}0.0772 \\
(2.55)^{* *}\end{array}$ \\
\hline Revenue-based Herfindahl index & $\begin{array}{c}0.0083 \\
(2.11)^{* *}\end{array}$ & $\begin{array}{c}0.0089 \\
(2.07)^{* *}\end{array}$ & $\begin{array}{c}0.0086 \\
(2.22)^{* *}\end{array}$ \\
\hline$Q$ & $\begin{array}{c}0.0026 \\
(1.79)^{*}\end{array}$ & $\begin{array}{c}0.0029 \\
(1.84)^{*}\end{array}$ & $\begin{array}{c}0.0034 \\
(2.21)^{* *}\end{array}$ \\
\hline FCF & $\begin{array}{c}-0.1144 \\
(-3.40)^{* * *}\end{array}$ & $\begin{array}{c}-0.1114 \\
(-3.13)^{* * *}\end{array}$ & $\begin{array}{c}-0.1158 \\
(-3.28)^{* * *}\end{array}$ \\
\hline DEBT & $\begin{array}{l}-0.0105 \\
(-0.47)\end{array}$ & $\begin{array}{l}-0.0194 \\
(-0.86)\end{array}$ & $\begin{array}{l}-0.0110 \\
(-0.50)\end{array}$ \\
\hline SIZE & $\begin{array}{c}-0.0137 \\
(-3.60)^{* * *}\end{array}$ & $\begin{array}{c}-0.0141 \\
(-3.57)^{* * *}\end{array}$ & $\begin{array}{c}-0.0131 \\
(-3.41)^{* * *}\end{array}$ \\
\hline FIRMRD & $\begin{array}{l}0.0015 \\
(1.57)\end{array}$ & $\begin{array}{l}0.0011 \\
(1.18)\end{array}$ & $\begin{array}{l}0.0016 \\
(1.60)\end{array}$ \\
\hline INDCON & $\begin{array}{l}-0.0029 \\
(-0.47)\end{array}$ & $\begin{array}{l}0.0015 \\
(0.23)\end{array}$ & $\begin{array}{l}-0.0030 \\
(-0.48)\end{array}$ \\
\hline INDRD & $\begin{array}{l}0.0107 \\
(0.15)\end{array}$ & $\begin{array}{l}-0.0038 \\
(-0.06)\end{array}$ & $\begin{array}{l}-0.0022 \\
(-0.03)\end{array}$ \\
\hline CSM & $\begin{array}{l}-0.0050 \\
(-0.56)\end{array}$ & $\begin{array}{l}-0.0049 \\
(-0.52)\end{array}$ & $\begin{array}{l}-0.0044 \\
(-0.49)\end{array}$ \\
\hline MULTIPLE & $\begin{array}{l}0.0069 \\
(1.02)\end{array}$ & $\begin{array}{l}0.0002 \\
(0.03)\end{array}$ & $\begin{array}{l}0.0024 \\
(0.41)\end{array}$ \\
\hline NEWNESS & $\begin{array}{l}0.0089 \\
(1.51)\end{array}$ & $\begin{array}{l}0.0083 \\
(1.32)\end{array}$ & $\begin{array}{l}0.0062 \\
(1.03)\end{array}$ \\
\hline TIME & $\begin{array}{l}0.0046 \\
(0.72)\end{array}$ & $\begin{array}{l}0.0032 \\
(0.41)\end{array}$ & $\begin{array}{l}0.0044 \\
(0.65)\end{array}$ \\
\hline FREQUENCY & $\begin{array}{c}0.0012 \\
(2.12)^{* *}\end{array}$ & $\begin{array}{l}0.0010 \\
(1.58)\end{array}$ & $\begin{array}{c}0.0012 \\
(2.07)^{* *}\end{array}$ \\
\hline INTEREST & $\begin{array}{c}-0.0019 \\
(-1.86)^{*}\end{array}$ & $\begin{array}{l}-0.0019 \\
(-1.72)^{*}\end{array}$ & $\begin{array}{l}-0.0021 \\
(-1.92)^{*}\end{array}$ \\
\hline BETA & $\begin{array}{l}-0.0049 \\
(-1.14)\end{array}$ & $\begin{array}{l}-0.0039 \\
(-0.89)\end{array}$ & $\begin{array}{l}-0.0019 \\
(-0.44)\end{array}$ \\
\hline MULTIPLE $\times$ NEWNESS & $\begin{array}{l}-0.0142 \\
(-1.38)\end{array}$ & $\begin{array}{l}-0.0067 \\
(-0.69)\end{array}$ & $\begin{array}{l}-0.0101 \\
(-1.06)\end{array}$ \\
\hline MULTIPLE $\times$ TIME & $\begin{array}{l}-0.0094 \\
(-0.82)\end{array}$ & $\begin{array}{c}0.0157 \\
(1.30)\end{array}$ & $\begin{array}{l}0.0011 \\
(0.10)\end{array}$ \\
\hline NEWNESS $\times$ TIME & $\begin{array}{l}-0.0092 \\
(-1.21)\end{array}$ & $\begin{array}{l}-0.0088 \\
(-0.96)\end{array}$ & $\begin{array}{l}-0.0092 \\
(-1.17)\end{array}$ \\
\hline MULTIPLE $\times$ NEWNESS $\times$ TIME & $\begin{array}{c}0.0247 \\
(1.68)^{*}\end{array}$ & $\begin{array}{l}0.0007 \\
(0.05)\end{array}$ & $\begin{array}{l}0.0144 \\
(1.02)\end{array}$ \\
\hline$N$ & 646 & 646 & 646 \\
\hline Adjusted $R^{2}$ & 0.283 & 0.254 & 0.291 \\
\hline$F$-value & $14.43^{* * *}$ & $12.55^{* * *}$ & $14.94^{* * *}$ \\
\hline
\end{tabular}


Table 9 (Continued)

\begin{tabular}{|c|c|c|c|}
\hline Variable & $\begin{array}{l}\text { Fama and French } \\
\text { Three-Factor Model }\end{array}$ & $\begin{array}{l}\text { Mean-Adjusted } \\
\text { Returns Model }\end{array}$ & $\begin{array}{l}\text { Market-Adjusted } \\
\text { Returns Model }\end{array}$ \\
\hline \multicolumn{4}{|c|}{$\begin{array}{l}\text { Panel B: Dependent Variable }=\text { Dollar Changes in the Market Value of the Announcing Firm } \\
\text { Announcement Period }\end{array}$} \\
\hline Intercept & $\begin{array}{c}-958.7481 \\
(-2.79)^{* * *}\end{array}$ & $\begin{array}{r}-1142.2556 \\
(-2.52)^{* *}\end{array}$ & $\begin{array}{r}-1172.8174 \\
(-3.20)^{* * *}\end{array}$ \\
\hline Revenue-based Herfindahl index & $\begin{array}{r}349.3089 \\
(2.30)^{* *}\end{array}$ & $\begin{array}{l}394.6571 \\
(2.60)^{* * *}\end{array}$ & $\begin{array}{l}408.3096 \\
(2.86)^{* * *}\end{array}$ \\
\hline$Q$ & $\begin{array}{l}23.4263 \\
(0.92)\end{array}$ & $\begin{array}{l}34.6715 \\
(0.82)\end{array}$ & $\begin{array}{l}59.3393 \\
(1.68)^{*}\end{array}$ \\
\hline FCF & $\begin{array}{c}290.5007 \\
(0.92)\end{array}$ & $\begin{array}{c}439.6275 \\
(0.82)\end{array}$ & $\begin{array}{c}462.6945 \\
(1.11)\end{array}$ \\
\hline DEBT & $\begin{array}{c}-246.0426 \\
(-1.00)\end{array}$ & $\begin{array}{c}-545.5788 \\
(-1.92)^{*}\end{array}$ & $\begin{array}{c}-195.3583 \\
(-0.78)\end{array}$ \\
\hline SIZE & $\begin{array}{l}221.5579 \\
(2.97)^{* * *}\end{array}$ & $\begin{array}{l}271.5643 \\
(2.83)^{* * *}\end{array}$ & $\begin{array}{l}261.3001 \\
(3.28)^{* * *}\end{array}$ \\
\hline FIRMRD & $\begin{array}{l}10.9918 \\
(2.38)^{* *}\end{array}$ & $\begin{array}{l}12.3406 \\
(2.28)^{* *}\end{array}$ & $\begin{array}{l}13.1538 \\
(2.64)^{* * *}\end{array}$ \\
\hline INDCON & $\begin{array}{c}-180.9967 \\
(-0.97)\end{array}$ & $\begin{array}{l}-2.3639 \\
(-0.01)\end{array}$ & $\begin{array}{c}-180.1477 \\
(-1.00)\end{array}$ \\
\hline INDRD & $\begin{array}{r}1483.7530 \\
(2.10)^{* *}\end{array}$ & $\begin{array}{c}1792.3572 \\
(1.88)^{*}\end{array}$ & $\begin{array}{c}1164.3666 \\
(1.46)\end{array}$ \\
\hline CSM & $\begin{array}{l}49.9705 \\
(0.26)\end{array}$ & $\begin{array}{c}-169.3828 \\
(-0.60)\end{array}$ & $\begin{array}{l}-68.5941 \\
(-0.30)\end{array}$ \\
\hline MULTIPLE & $\begin{array}{c}160.8734 \\
(1.27)\end{array}$ & $\begin{array}{l}20.6583 \\
(0.17)\end{array}$ & $\begin{array}{l}90.3620 \\
(0.74)\end{array}$ \\
\hline NEWNESS & $\begin{array}{l}14.4413 \\
(0.11)\end{array}$ & $\begin{array}{l}-30.1668 \\
(-0.23)\end{array}$ & $\begin{array}{l}-22.5779 \\
(-0.19)\end{array}$ \\
\hline TIME & $\begin{array}{c}110.4476 \\
(0.94)\end{array}$ & $\begin{array}{l}-20.4488 \\
(-0.09)\end{array}$ & $\begin{array}{c}121.4526 \\
(0.83)\end{array}$ \\
\hline FREQUENCY & $\begin{array}{l}3.2809 \\
(0.13)\end{array}$ & $\begin{array}{l}-18.4912 \\
(-0.87)\end{array}$ & $\begin{array}{l}10.7551 \\
(0.49)\end{array}$ \\
\hline INTEREST & $\begin{array}{l}-26.5761 \\
(-1.65)^{*}\end{array}$ & $\begin{array}{l}-25.3856 \\
(-1.41)\end{array}$ & $\begin{array}{l}-31.2396 \\
(-1.90)^{*}\end{array}$ \\
\hline BETA & $\begin{array}{l}-4.1080 \\
(-0.07)\end{array}$ & $\begin{array}{l}-25.5114 \\
(-0.35)\end{array}$ & $\begin{array}{l}14.8300 \\
(0.23)\end{array}$ \\
\hline MULTIPLE $\times$ NEWNESS & $\begin{array}{c}-243.2012 \\
(-1.25)\end{array}$ & $\begin{array}{c}-115.0146 \\
(-0.65)\end{array}$ & $\begin{array}{c}-208.4366 \\
(-1.16)\end{array}$ \\
\hline MULTIPLE $\times$ TIME & $\begin{array}{c}-316.2046 \\
(-0.70)\end{array}$ & $\begin{array}{c}685.6576 \\
(1.01)\end{array}$ & $\begin{array}{c}144.6383 \\
(0.25)\end{array}$ \\
\hline NEWNESS $\times$ TIME & $\begin{array}{c}-122.7461 \\
(-0.73)\end{array}$ & $\begin{array}{l}13.3988 \\
(0.05)\end{array}$ & $\begin{array}{c}-179.9345 \\
(-0.96)\end{array}$ \\
\hline MULTIPLE $\times$ NEWNESS $\times$ TIME & $\begin{array}{c}485.8874 \\
(1.01)\end{array}$ & $\begin{array}{c}-413.0097 \\
(-0.58)\end{array}$ & $\begin{array}{l}93.9937 \\
(0.15)\end{array}$ \\
\hline$N$ & 646 & 646 & 646 \\
\hline Adjusted $R^{2}$ & 0.021 & 0.029 & 0.050 \\
\hline$F$-value & $1.71^{* *}$ & $2.01^{* * *}$ & $2.78^{* * *}$ \\
\hline
\end{tabular}


Table 9 (Continued)

Notes:

This table presents cross-sectional regression analyses of the two-day $(-1,0)$ cumulative abnormal returns and dollar changes in the market value of the announcing firms against organizational form and control variables for the sample of new product introductions, using the Fama and French (1992 and 1993) three-factor model, the mean-adjusted returns model, and the market-adjusted returns model. Dollar changes in the market value of the firms over the two-day announcement period are computed by multiplying the two-day announcement-period abnormal returns by the announcing firms' market value of equity for the fiscal year preceding the announcement. The dollar changes in the market value are converted to 1999 dollars using the Consumer Price Index. All the explanatory variables are defined in Table 8 . The $t$-values in parentheses are computed with heteroskedasticity-consistent standard errors (White, 1980). ${ }^{* * *},{ }^{* *}$ and ${ }^{*}$ represent $1 \%, 5 \%$ and $10 \%$ significance levels, respectively.

\section{CONCLUSION}

This paper examines the importance of organizational form in explaining the economic impact of corporate new product strategies. While previous studies examine the valuation effect of corporate new product strategies and its determinants, the important issue of how organizational form affects the value of corporate new product strategies has so far escaped the attention of researchers. This study attempts to fill this gap by examining the relation between organizational form and the economic impact of corporate new product strategies through testing the efficient investment hypothesis versus the internal capital markets hypothesis. The efficient investment hypothesis predicts that the economic impact of new product announcements is more favorable for new product strategies by focused firms than for those by diversified firms, because focused firms tend to have better investment opportunities and are more likely to make positive NPV investments. On the other hand, the internal capital markets hypothesis predicts that the economic impact associated with the announcements of corporate new product strategies is more favorable for diversified firms, because with a larger internal capital market, diversified firms allocate resources more efficiently and are more likely to invest in profitable projects.

I investigate a sample of firms that announced new product introductions during the period 1989-1999. I show that consistent with previous studies, announcements of new product introductions are, on average, associated with a significantly positive effect on shareholder value. Further dividing the sample by firms with focused activities and those with diversified activities, I find that introducing firms with focused activities show a significantly positive wealth effect associated with their announcements of new product introductions, whereas firms with diversified activities have an insignificant wealth effect associated with such announcements. In crosssectional regression analyses, I show a significantly positive relation between the economic impact of new product announcements on shareholder value and the degree of corporate focus. The results hold even after controlling for other factors suggested in the literature that could affect the value of corporate new product introductions. My findings suggest that the efficient investment hypothesis dominates the internal capital markets hypothesis. Focused firms are more likely to make positive NPV investments and hence their new product investments are more worthwhile than those by diversified firms. 


\section{REFERENCES}

Acs, Z. J. and D. B. Audretsch (1988), 'Innovation in Large and Small Firms: An Empirical Analysis', American Economic Review, Vol. 78, pp. 678-90.

Anderson, R. C., T. W. Bates, J. M. Bizjak and M. L. Lemmon (2000), 'Corporate Governance and Firm Diversification', Financial Management, Vol. 29, pp. 5-22.

Baldwin, W. L. and G. L. Childs (1969), 'The Fast Second and Rivalry in Research and Development', Southern Economic Journal, Vol. 36, pp. 18-24.

Barclay, M. J. and C. W. Smith (1995a), 'The Maturity Structure of Corporate Debt', Journal of Finance, Vol. 50, pp. 609-31.

(1995b), 'The Priority Structure of Corporate Liabilities', Journal of Finance, Vol. 50, pp. 899-917.

Barnes, E. and G. Hardie-Brown (2006), 'The Diversification Puzzle: Revisiting the Value Impact of Diversification for UK Firms', Journal of Business Finance $\mathcal{E}$ Accounting, Vol. 33, pp. 1508-34.

Berger, P. G. and E. Ofek (1995), 'Diversification's Effect on Firm Value', Journal of Financial Economics, Vol. 37, pp. 39-65.

- (1999), 'Causes and Effects of Corporate Refocusing Programs', Review of Financial Studies, Vol. 12, pp. 311-45.

Bernardo, A. E. and B. Chowdhry (2002), 'Resources, Real Options, and Corporate Strategy', Journal of Financial Economics, Vol. 63, pp. 211-34.

Bittlingmayer, G. and T. W. Hazlett (2000), 'DOS Kapital: Has Antitrust Action Against Microsoft Created Value in the Computer Industry'? Journal of Financial Economics, Vol. 55, pp. 329-59.

Bulow, J. I., J. D. Geanakoplos and P. D. Klemperer (1985), 'Multimarket Oligopoly: Strategic Substitutes and Complements', Journal of Political Economy, Vol. 93, pp. 488-511.

Campa, J. M. and S. Kedia (2002), 'Explaining the Diversification Discount', Journal of Finance, Vol. 57, pp. 1731-62.

Cardinal, L. B. and T. C. Opler (1995), 'Corporate Diversification and Innovative Efficiency: An Empirical Study', Journal of Accounting and Economics, Vol. 19, pp. 365-81.

Chan, S. H., J. D. Martin and J. W. Kensinger (1990), 'Corporate Research and Development Expenditures and Share Value', Journal of Financial Economics, Vol. 26, pp. 255-76.

Chaney, P. K., T. M. Devinney and R. S. Winer (1991), 'The Impact of New Product Introductions on the Market Value of Firms', Journal of Business, Vol. 64, pp. 573-610.

Chang, S. C. and S. S. Chen (2002), 'The Wealth Effect of Domestic Joint Ventures: Evidence from Taiwan', Journal of Business Finance $\mathcal{E}$ Accounting, Vol. 29, pp. 201-22.

Chauvin, K. W. and M. Hirschey (1993), 'Advertising, R\&D Expenditures and Market Value of the Firm', Financial Management, Vol. 22, pp. 128-40.

Chen, S. S. (2006), 'The Economic Impact of Corporate Capital Expenditures: Focused Firms versus Diversified Firms', Journal of Financial and Quantitative Analysis, Vol. 41, pp. 34155.

- and K. W. Ho (1997), 'Market Response to Product-Strategy and Capital-Expenditure Announcements in Singapore: Investment Opportunities and Free Cash Flow', Financial Management, Vol. 26, pp. 82-88.

and K. H. Ik (2005), 'The Wealth Effect of New Product Introductions on Industry Rivals', Journal of Business, Vol. 78, pp. 969-96.

and C. F. Lee (2002), 'How Does Strategic Competition Affect Firm Values? A Study of New Product Announcements', Financial Management, Vol. 31, pp. 6784.

Chung, K. H. and S. W. Pruitt (1994), 'Simple Approximation of Tobin's q', Financial Management, Vol. 23, pp. 70-74.

Comanor, W. S. (1967), 'Market Structure, Product Differentiation, and Industrial Research', Quarterly Journal of Economics, Vol. 81, pp. 639-57.

Comment, R. and G. A. Jarrell (1995), 'Corporate Focus and Stock Returns', Journal of Financial Economics, Vol. 37, pp. 67-87.

D'Aveni, R. A. (1994), Hypercompetition: Managing the Dynamics of Strategic Maneuvering (New York: Free Press). 
Denis, D. J., D. K. Denis and A. Sarin (1997), 'Agency Problems, Equity Ownership, and Corporate Diversification', Journal of Finance, Vol. 52 135-60.

Dodd, P. and J. B. Warner (1983), 'On Corporate Governance: A Study of Proxy Contests', Journal of Financial Economics, Vol. 11, pp. 401-38.

Doukas, J. and L. N. Switzer (1992), 'The Stock Market's View of R\&D Spending and Market Concentration', Journal of Economics and Business, Vol. 44, pp. 95-114.

Fama, E. F. and K. R. French (1992), 'The Cross-Section of Expected Stock Returns', Journal of Finance, Vol. 47, pp. 427-65.

(1993), 'Common Risk Factors in the Returns on Stocks and Bonds', Journal of Financial Economics, Vol. 33, pp. 3-56.

Firth, R. W. and V. K. Narayanan (1996), 'New Product Strategies of Large, Dominant Product Manufacturing Firms: An Exploratory Analysis', Journal of Product Innovation Management, Vol. 13, pp. 334-47.

Fluck, Z. and A. W. Lynch (1999), 'Why Do Firms Merge and Then Divest? A Theory of Financial Synergy', Journal of Business, Vol. 72, pp. 319-46.

Gregory, A. (2005), 'The Long Run Abnormal Performance of UK Acquirers and the Free Cash Flow Hypothesis', Journal of Business Finance $\mathcal{E}$ Accounting, Vol. 32, pp. 777-814.

Guenther, D. A. and A. J. Rosman (1994), 'Difference Between Compustat and CRSP SIC Codes and Related Effects on Research', Journal of Accounting and Economics, Vol. 18, pp. 115-28.

Hadlock, C. J., M. Ryngaert and S. Thomas (2001), 'Corporate Structure and Equity Offerings: Are There Benefits to Diversify'? Journal of Business, Vol. 74, pp. 613-35.

Hambrick, D. C. and I. C. MacMillan (1985), 'Efficiency of Product R\&D in Business Units: The Role of Strategic Context', Academy of Management Journal, Vol. 28, pp. 527-47.

Hendricks, K. B. and V. R. Singhal (1997), 'Delays in New Product Introductions and the Market Value of Firm: The Consequences of Being Late to the Market', Management Science, Vol. 43, pp. 422-36.

Hyland, D. C. and J. D. Diltz (2002), 'Why Firms Diversify: An Empirical Examination', Financial Management, Vol. 31, pp. 51-81.

Jensen, M. C. (1986), 'Agency Costs of Free Cash Flow, Corporate Finance, and Takeovers', American Economic Review, Vol. 76, pp. 323-29.

Jovanovic, B. and G. M. MacDonald (1994), 'The Life Cycle of a Competitive Industry', Journal of Political Economy, Vol. 102, pp. 322-47.

Kahle, K. M. and R. A. Walkling (1996), 'The Impact of Industry Classifications on Financial Research', Journal of Financial and Quantitative Analysis, Vol. 31, pp. 309-35.

Kelm, K. M., V. K. Narayanan and G. E. Pinches (1995), 'Shareholder Value Creation During R\&D Innovation and Commercialization Stages', Academy of Management Journal, Vol. 38, pp. 770-86.

Kim, W. S., L. Esmeralda, T. J. Park and E. Zychowicz (2005), 'The Wealth Effects of Capital Investment Decisions: An Empirical Comparison of Korean Chaebol and Non-Chaebol Firms', Journal of Business Finance Eं Accounting, Vol. 32, pp. 945-71.

Kleinschmidt, E. J. and R. G. Cooper (1991), 'The Impact of Product Innovativeness on Performance', Journal of Product Innovation Management, Vol. 8, pp. 240-51.

Kovenock, D. and G. M. Phillips (1997), 'Capital Structure and Product Market Behavior: An Examination of Plant Exit and Investment Decisions', Review of Financial Studies, Vol. 10, pp. 767-803.

Lang, L. H. P. and R. M. Stulz (1992), 'Contagion and Competitive Intra-Industry Effects of Bankruptcy Announcements', Journal of Financial Economics, Vol. 32, pp. 45-60.

- (1994), 'Tobin's q, Corporate Diversification and Firm Performance', Journal of Political Economy, Vol. 102, pp. 1248-80. and R. A. Walkling (1989), 'Managerial Performance, Tobin's $q$, and the Gains from Successful Tender Offers', Journal of Financial Economics, Vol. 24, pp. 137-54.

(1991), 'A Test of the Free Cash Flow Hypothesis: The Case of Bidder Returns', Journal of Financial Economics, Vol. 29, pp. 315-35.

Lee, H., K. G. Smith, C. M. Grimm and A. Schomburg (2000), 'Timing, Order and Durability of New Product Advantages with Imitation', Strategic Management Journal, Vol. 21, pp. 23-30. 
Lehn, K. and A. Poulsen (1989), 'Free Cash Flow and Stockholder Gains in Going Private Transactions', Journal of Finance, Vol. 44, pp. 771-87.

Lie, E. (2000), 'Excess Funds and Agency Problems: An Empirical Study of Incremental Cash Disbursements', Review of Financial Studies, Vol. 13, pp. 219-48.

- (2002), 'Do Firms Undertake Self-Tender Offers to Optimize Capital Structure'? Journal of Business, Vol. 75, pp. 609-39.

Lindenberg, E. B. and S. A. Ross (1981), 'Tobin's $q$ Ratio and Industrial Organization', Journal of Business, Vol. 54, pp. 1-32.

Link, A. L. and J. E. Long (1981), 'The Simple Economics of Basic Science Research', Journal of Political Economy, Vol. 67, pp. 297-306.

Lins, K. V. and H. Servaes (2002), 'Is Corporate Diversification Beneficial in Emerging Markets'? Financial Management, Vol. 31, pp. 5-31.

Mansfield, E., M. Schwartz and S. Wagner (1981), 'Imitation Costs and Patents: An Empirical Study', Economic Journal, Vol. 91, pp. 907-18.

Martin, J. D. and A. Sayrak (2003), 'Corporate Diversification and Shareholder Value: A Survey of Recent Literature', Journal of Corporate Finance, Vol. 9, pp. 37-57.

Meyer, M., P. Milgrom and J. Roberts (1992), 'Organizational Prospects, Influence Costs, and Ownership Changes', Journal of Economics and Management Strategy, Vol. 1, pp. 9-35.

Meyer, M. H. and E. B. Roberts (1986), 'New Product Strategy in Small Technology-Based Firms: A Pilot Study', Management Science, Vol. 32, pp. 806-21.

Myers, S. C. (1977), 'Determinants of Corporate Borrowing', Journal of Financial Economics, Vol. 5, pp. 147-75.

Palepu, K. (1985), 'Diversification Strategy, Profit Performance and the Entropy Measure', Strategic Management Journal, Vol. 6, pp. 239-55.

Phillips, A. (1966), 'Patents, Potential Competition, and Technical Progress', American Economic Review, Vol. 56, pp. 301-10.

Phillips, G. M. (1995), 'Increased Debt and Industry Product Markets: An Empirical Analysis', Journal of Financial Economics, Vol. 37, pp. 189-238.

Rajan, R., H. Servaes and L. Zingales (2000), 'The Cost of Diversity: The Diversification Discount and Inefficient Investment', Journal of Finance, Vol. 55, pp. 35-80.

Saloner, G., A. Shepard and J. Podolny (2001), Strategic Management (New York: John Wiley \& Sons).

Scharfstein, D. S. (1998), 'The Dark Side of Internal Capital Markets II: Evidence from Diversified Conglomerates', NBER Working Paper No. 6352. - and J. C. Stein (2000), 'The Dark Side of Internal Capital Markets: Divisional RentSeeking and Inefficient Investment', Journal of Finance, Vol. 55, pp. 2537-64.

Servaes, H. (1996), 'The Value of Diversification During the Conglomerate Merger Wave', Journal of Finance, Vol. 51, pp. 1201-26.

Shin, H. H. and R. M. Stulz (1998), 'Are Internal Capital Markets Efficient'? Quarterly Journal of Economics, Vol. 113, pp. 531-52.

Song, M. H. and R. A. Walkling (2000), 'Abnormal Returns to Rivals of Acquisition Targets: A Test of the "Acquisition Probability Hypothesis", Journal of Financial Economics, Vol. 55, pp. 143-72.

Stein, J. C. (1997), 'Internal Capital Markets and the Competition for Corporate Resources', Journal of Finance, Vol. 52, pp. 111-33.

Stulz, R. M. (1990), 'Managerial Discretion and Optimal Financing Policies', Journal of Financial Economics, Vol. 26, pp. 3-27.

Sundaram, A. K., T.A. John and K. John (1996), 'An Empirical Analysis of Strategic Competition and Firm Values: The Case of R\&D Competition', Journal of Financial Economics, Vol. 40, pp. $459-86$.

Szewczyk, S. H., G. P. Tsetsekos and Z. Zantout (1996), 'The Valuation of Corporate R\&D Expenditures: Evidence from Investment Opportunities and Free Cash Flow', Financial Management, Vol. 25, pp. 105-10.

Thomas, S. (2002), 'Firm Diversification and Asymmetric Information: Evidence from Analysts' Forecasts and Earnings Announcements', Journal of Financial Economics, Vol. 64, pp. 373-96. 
Trigeorgis, L. (1996), Real Options: Managerial Flexibility and Strategy in Resource Allocation (Cambridge: The MIT Press).

Waarts, E. and B. Wierenga (2000), 'Explaining Competitors' Reactions to New Product Introductions: The Roles of Event Characteristics, Managerial Interpretation, and Competitive Context', Marketing Letters, Vol. 11, pp. 67-79.

Wernerfelt, B. and C. A. Montgomery (1988), 'Tobin's $q$ and the Importance of Focus in Firm Performance', American Economic Review, Vol. 78, pp. 246-50.

Weston, J. F. (1970), 'The Nature and Significance of Conglomerate Firms', St. John Law Review, Vol. 44, pp. 66-80.

White, H. (1980), 'A Heteroskedasticity-Consistent Covariance Matrix Estimator and a Direct Test for Heteroskedasticity', Econometrica, Vol. 48, pp. 817-38.

Williamson, O. E. (1986), Economic Organization: Firms, Markets and Policy Control (New York: New York University Press). 